Atmos. Chem. Phys., 13, 11101-11120, 2013

www.atmos-chem-phys.net/13/11101/2013/

doi:10.5194/acp-13-11101-2013

(c) Author(s) 2013. CC Attribution 3.0 License.

\title{
Constraints on emissions of carbon monoxide, methane, and a suite of hydrocarbons in the Colorado Front Range using observations of ${ }^{14} \mathrm{CO}_{2}$
}

\author{
B. W. LaFranchi ${ }^{1}$, G. Pétron ${ }^{2,3}$, J. B. Miller ${ }^{2,3}$, S. J. Lehman ${ }^{4}$, A. E. Andrews ${ }^{2}$, E. J. Dlugokencky ${ }^{2}$, B. Hall ${ }^{2}$, \\ B. R. Miller ${ }^{2,3}$, S. A. Montzka ${ }^{2}$, W. Neff ${ }^{3,5}$, P. C. Novelli ${ }^{2}$, C. Sweeney ${ }^{2,3}$, J. C. Turnbull ${ }^{3,6}$, D. E. Wolfe ${ }^{5}$, P. P. Tans ${ }^{2}$, \\ K. R. Gurney ${ }^{7}$, and T. P. Guilderson ${ }^{1}$ \\ ${ }^{1}$ Center for Accelerator Mass Spectrometry (CAMS), Lawrence Livermore National Laboratory, Livermore, CA 94550, USA \\ ${ }^{2}$ Global Monitoring Division (GMD), NOAA Earth System Research Laboratory, Boulder, CO 80305, USA \\ ${ }^{3}$ Cooperative Institute for Research in Environmental Sciences (CIRES), University of Colorado, Boulder CO 80309, USA \\ ${ }^{4}$ Institute for Arctic and Alpine Research (INSTAAR), University of Colorado, Boulder 80305, USA \\ ${ }^{5}$ Physical Sciences Division, NOAA Earth System Research Laboratory, Boulder, CO 80305, USA \\ ${ }^{6}$ National Isotope Centre, GNS Science, Lower Hutt 5040, New Zealand \\ ${ }^{7}$ School of Life Sciences, Arizona State University, Tempe, AZ 85287, USA
}

Correspondence to: B. W. LaFranchi (lafranchi2@1lnl.gov)

Received: 6 December 2012 - Published in Atmos. Chem. Phys. Discuss.: 15 January 2013

Revised: 17 August 2013 - Accepted: 4 September 2013 - Published: 15 November 2013

\begin{abstract}
Atmospheric radiocarbon $\left({ }^{14} \mathrm{C}\right)$ represents an important observational constraint on emissions of fossil-fuel derived carbon into the atmosphere due to the absence of ${ }^{14} \mathrm{C}$ in fossil fuel reservoirs. The high sensitivity and precision that accelerator mass spectrometry (AMS) affords in atmospheric ${ }^{14} \mathrm{C}$ analysis has greatly increased the potential for using such measurements to evaluate bottom-up emissions inventories of fossil fuel $\mathrm{CO}_{2}\left(\mathrm{CO}_{2} \mathrm{ff}\right)$, as well as those for other co-emitted species. Here we use observations of ${ }^{14} \mathrm{CO}_{2}$ and a series of primary hydrocarbons and combustion tracers from discrete air samples collected between June 2009 and September 2010 at the National Oceanic and Atmospheric Administration Boulder Atmospheric Observatory (BAO; Lat: $40.050^{\circ} \mathrm{N}$, Lon: $105.004^{\circ} \mathrm{W}$ ) to derive emission ratios of each species with respect to $\mathrm{CO}_{2} \mathrm{ff}$. The $\mathrm{BAO}$ tower is situated at the boundary of the Denver metropolitan area to the south and a large industrial and agricultural region to the north and east, making it an ideal location to study the contrasting mix of emissions from the activities in each region. The species considered in this analysis are carbon monoxide $(\mathrm{CO})$, methane $\left(\mathrm{CH}_{4}\right)$, acetylene $\left(\mathrm{C}_{2} \mathrm{H}_{2}\right)$, benzene $\left(\mathrm{C}_{6} \mathrm{H}_{6}\right)$, and $\mathrm{C}_{3}-\mathrm{C}_{5}$ alkanes. We estimate emissions for a subset of these species by using the Vulcan high resolution
\end{abstract}

$\mathrm{CO}_{2} \mathrm{ff}$ emission data product as a reference. We find that $\mathrm{CO}$ is overestimated in the 2008 National Emissions Inventory (NEI08) by a factor of $\sim 2$. A close evaluation of the inventory suggests that the ratio of $\mathrm{CO}$ emitted per unit fuel burned from on-road gasoline vehicles is likely over-estimated by a factor of 2.5. Using a wind-directional analysis of the data, we find enhanced concentrations of $\mathrm{CH}_{4}$, relative to $\mathrm{CO}_{2} \mathrm{ff}$, in air influenced by emissions to the north and east of the BAO tower when compared to air influenced by emissions in the Denver metro region to the south. Along with enhanced $\mathrm{CH}_{4}$, the strongest enhancements of the $\mathrm{C}_{3}-\mathrm{C}_{5}$ alkanes are also found in the north and east wind sector, suggesting that both the alkane and $\mathrm{CH}_{4}$ enhancements are sourced from oil and gas fields located to the northeast, though it was not possible to rule out the contribution of non oil and gas $\mathrm{CH}_{4}$ sources.

\section{Introduction}

The relative abundance of radiocarbon $\left({ }^{14} \mathrm{C}\right)$ in $\mathrm{CO}_{2}\left({ }^{14} \mathrm{CO}_{2}\right)$ is a powerful tracer that provides the least biased and most direct means to observe fossil fuel derived $\mathrm{CO}_{2}$ in the atmosphere (Zondervan and Meijer, 1996; Levin et al., 2003; 
Turnbull et al., 2006; Hsueh et al., 2007; Levin and Karstens, 2007; Turnbull et al., 2009; Van der Laan et al., 2010). Fossil fuels are completely devoid of ${ }^{14} \mathrm{C}$, as is the $\mathrm{CO}_{2}$ resulting from its combustion, because the half life of ${ }^{14} \mathrm{C}$ is short $(\sim 5700 \mathrm{yr}$; Godwin, 1962) in relation to the residence times of carbon in fossil reservoirs, where no additional ${ }^{14} \mathrm{C}$ production occurs. Since all other sources of $\mathrm{CO}_{2}$ to the atmosphere stem from carbon reservoirs (the ocean and biosphere) that are nearly in equilibrium with the isotopic composition of the atmosphere itself, the atmosphere exhibits gradients in ${ }^{14} \mathrm{CO}_{2}$ that can be quantitatively traced to addition of $\mathrm{CO}_{2}$ from fossil fuel combustion (Turnbull et al., 2007; Graven et al., 2009; Levin et al., 2010).

Prior to nuclear weapons testing, which artificially increased the ${ }^{14} \mathrm{CO}_{2}$ content of the atmosphere, the rise in atmospheric $\mathrm{CO}_{2}$ resulting from fossil fuel combustion could be observed on global scales as a decrease in ${ }^{14} \mathrm{CO}_{2}$, widely known as the Suess effect (Suess, 1955). While ${ }^{14} \mathrm{CO}_{2}$ is produced naturally in the upper atmosphere from cosmogenic radiation, the abundance of ${ }^{14} \mathrm{CO}_{2}$ in the modern atmosphere was strongly impacted by above-ground nuclear testing that occurred in the middle part of the 20th century. Since the atmospheric nuclear weapons test ban was put in place, the decrease in ${ }^{14} \mathrm{CO}_{2}$, which has been observed at a number of global background monitoring sites (Levin and Kromer, 2004; Turnbull et al., 2007; Currie et al., 2011; Graven et al., 2012a, b; Lehman et al., 2013), has been influenced primarily by the exchange of atmospheric ${ }^{14} \mathrm{CO}_{2}$ with the oceanic and terrestrial carbon reservoirs. In recent years, however, the atmospheric decline has been increasingly influenced by isotopic dilution due to the Seuss effect, as fossil fuel combustion increases and as the atmosphere, ocean, and terrestrial carbon reservoirs approach equilibrium with the "bomb spike". On regional scales, locally emitted $\mathrm{CO}_{2}$ from fossil fuel combustion can be detected as a depletion of ${ }^{14} \mathrm{C}:{ }^{12} \mathrm{C}$ relative to background air. These observed gradients result from what we define as "recently added" fossil-fuel $\mathrm{CO}_{2}$ $\left(\mathrm{CO}_{2} \mathrm{ff}\right)$.

Observations of ${ }^{14} \mathrm{CO}_{2}$ downwind of source regions are of great interest, not only for the evaluation of fossil $\mathrm{CO}_{2}$ emissions inventories, but also as a means to better understand emissions of a range of trace gases associated or colocated with the combustion of fossil fuels (Turnbull et al., 2011; Miller et al., 2012). Bottom-up inventories of these trace gases carry significant uncertainties because of the difficulty in quantifying the relationship between the mass of fuel consumed and the mass of trace gas emitted. Emissions of by-products, including species such as carbon monoxide $(\mathrm{CO})$, methane $\left(\mathrm{CH}_{4}\right)$, acetylene $\left(\mathrm{C}_{2} \mathrm{H}_{2}\right)$, and benzene $\left(\mathrm{C}_{6} \mathrm{H}_{6}\right)$ depend on a number of variables including fuel type, combustion temperature, the extent of tail-pipe or flue-stack "scrubbing", and oxidant-to-fuel ratio. For example, it has long been known from observations that the National Emissions Inventory (NEI) appears to over-estimate observed anthropogenic emissions of $\mathrm{CO}$ in the United States by a fac- tor of 1.5-2 (Parrish, 2006; Hudman et al., 2008; Miller et al., 2008, 2012). Further, there are a number of industrial activities that lead to non-combustion emissions of gases impacting air quality and climate from leaks in transmission lines, venting of storage tanks, and other processes, in which case, quantifying emissions based on readily available fuel use, production, or activity statistics can lead to large uncertainties. In contrast, the amount of $\mathrm{CO}_{2}$ emitted per unit of fuel combusted can be derived stoichiometrically with relatively high accuracy. Accordingly, the bottom-up inventory of fossil fuel derived $\mathrm{CO}_{2}$ in the United States (e.g. EPA, 2012) and in most developed countries is thought to be relatively reliable. Estimates of annual fossil $\mathrm{CO}_{2}$ emissions for developed countries are thought to be reliable to better than $\sim 8 \%$ (Nassar et al., 2013), although uncertainties become larger at smaller spatial and temporal scales (Andres et al., 2012).

Atmospheric observations provide a direct means of improving emissions estimates for various combustion and industrial tracers and of evaluating existing bottom-up emissions estimates, and is especially important for those species that can affect air quality, human health, and climate. One relatively simple strategy for deriving emissions based on atmospheric observations is the use of tracer/tracer enhancement ratios in which emission ratios of two well-correlated species are inferred from the ratio of the observed mole fraction enhancements (with respect to background observations) of one species to the other. For gases with lifetimes comparable to the transit times between emission and measurement, a simple photochemical age model can be used to extrapolate back from the time of the observation to derive the ratio at the time of emission (Lee et al., 2006; Warneke et al., 2007). Then, if emissions of one of the tracers are relatively well defined for the geographic area that the observations are sensitive to, emissions of the other tracer can be calculated from the inferred emission ratio. Uncertainties for this method are minimized when both tracers have long atmospheric lifetimes and slow atmospheric production rates on the time scales relevant to the source-receptor distances. A major advantage of this approach comes from its computational simplicity. Additionally, since all tracers are expected to be mixed and transported in the same way if their sources are co-located, this approach reduces the sensitivity of the analysis on uncertainties in transport and boundary layer calculations.

The Vulcan high resolution fossil fuel $\mathrm{CO}_{2}$ data product (Gurney et al., 2009) provides an ideal reference emissions dataset for use in these tracer/tracer approaches at local-toregional scales, but large uncertainties in its biogenic sources and sinks can complicate the use of $\mathrm{CO}_{2}$ in inferring emissions of other fossil fuel combustion tracers (e.g. Miller et al., 2012). Thus, to take advantage of the photochemical stability of $\mathrm{CO}_{2}$ and the availability of the relatively accurate fossil fuel $\mathrm{CO}_{2}$ emissions inventories, measurements of ${ }^{14} \mathrm{CO}_{2}$ can be used to isolate the fossil fuel contribution to the observed 
$\mathrm{CO}_{2}$. Here we describe observations of ${ }^{14} \mathrm{CO}_{2}$ and other trace gases made between late June 2009 and September 2010 at the Boulder Atmospheric Observatory (BAO), a $300 \mathrm{~m}$ tall tower located $35 \mathrm{~km}$ north of Denver, $\mathrm{CO}$ (Lat $40.05^{\circ} \mathrm{N}$, Lon $105.01^{\circ} \mathrm{W}$ ) in Weld County. BAO is one of 9 towers in the NOAA Earth System Research Laboratory, Global Monitoring Division (NOAA-GMD, hereinafter) tall tower network (Andrews et al., 2013). It is one of 7 towers in the network that is monitoring $\mathrm{CO}_{2}$ and $\mathrm{CO}$ continuously and collecting air samples daily for multiple species analysis and one of 6 that also measures ${ }^{14} \mathrm{CO}_{2}$ in discrete air samples. The observations presented here represent the first report of ${ }^{14} \mathrm{CO}_{2}$ observations from this network.

This study builds on a previous effort to characterize emissions of volatile organic compounds (VOCs) and $\mathrm{CH}_{4}$ from oil and gas production and drilling operations in Weld County using both bottom-up and top-down approaches for 2008 (Pétron et al., 2012). We will refer to this prior study as the Colorado Front Range Pilot Study (CFRPS, hereafter), in which the authors made use of observations at BAO in combination with those from a mobile platform to determine emission magnitudes and emission signatures of individual methane sources, including oil and gas wells, natural gas processing plants, condensate storage tanks, landfills, cattle feed-lots, and waste water treatment plants. Continuous wind measurements at BAO enabled wind-sector specific analyses of atmospheric composition, which showed that trace gas concentrations measured at BAO are influenced most substantially by two different source regions: oil and gas fields to the northeast (from a region known as the Denver Julesberg Basin, or DJB) and urban-type emissions from the Denver metro region to the south. They found that air arriving at BAO from the northeast exhibits strong enhancements in alkanes, including methane, resembling enhancements (based on tracer/tracer ratios) similar to those sampled on the mobile platform within the DJB. These results suggested that oil and gas operations are the dominant emitters of alkanes, including methane in the region.

In this study, we use ${ }^{14} \mathrm{CO}_{2}$ to derive $\mathrm{CO}_{2}$ ff mole fractions and show that $\mathrm{CO}_{2} \mathrm{ff}$ exhibits strong correlations with a variety of trace gases in the region, both from combustion and non-combustion sources, allowing for the evaluation of emissions from a range of different source-types. We estimate emission ratios for a number of important trace gases being transported to the site from the DJB as well as from the Denver metro region. The variability in tracer/ $\mathrm{CO}_{2} \mathrm{ff}$ ratios with wind direction is analyzed in order to evaluate regional differences in emission sources, relative to $\mathrm{CO}_{2} \mathrm{ff}$ sources. For the trace gases related to the oil and gas industry, which exhibit strong wind-direction dependent enhancement ratios relative to $\mathrm{CO}_{2} \mathrm{ff}$, deriving emissions estimates is challenging due to uncertainty in the precise geographical area of emissions that the observations are sensitive to. In the cases of $\mathrm{CO}$ and $\mathrm{C}_{2} \mathrm{H}_{2}$, however, it is shown that the emission ratio is insensitive to the presumed area of emissions influencing the observations, and top-down emissions for these two tracers can be reliably estimated for the region. The primary advantage of this approach is that by using the Vulcan data product (Gurney et al., 2009) as a quantitative reference, which is reliable nationwide to within $20 \%$ at the county level on annual time-scales (Gurney et al., 2011), we maximize confidence in the derived top-down emission magnitudes.

\section{Methods}

\subsection{Site description}

The BAO tower is located $25 \mathrm{~km}$ east-northeast of Boulder and $35 \mathrm{~km}$ north of Denver $\left(40.05^{\circ} \mathrm{N}, 105.01^{\circ} \mathrm{W}\right)$. The base of the tower is at $1584 \mathrm{~m}$ above sea level (a.s.1.). As shown in Fig. 1, BAO is located at the southwestern edge of the DJB where a very large and dense network of oil and gas wells exists. Since late 2007 NOAA-GMD has been collecting discrete air samples approximately daily from $300 \mathrm{~m}$. The air is collected in glass flasks and analyzed at NOAA-GMD for a suite of $\sim 50$ trace gases and then circulated to the University of Colorado's Institute of Arctic and Alpine Research (INSTAAR) for stable isotope measurements in $\mathrm{CO}_{2}$ and $\mathrm{CH}_{4}$ and preparation for ${ }^{14} \mathrm{CO}_{2}$ measurement. The Center for Accelerator Mass Spectrometry (CAMS) at Lawrence Livermore National Laboratory (LLNL), which performed the ${ }^{14} \mathrm{CO}_{2}$ measurements reported here, has participated in the NOAA-GMD ${ }^{14} \mathrm{CO}_{2}$ discrete air sample measurement program since 2009. This study focuses on data collected between late June 2009 and September 2010, over which time 145 samples were analyzed for ${ }^{14} \mathrm{CO}_{2}$. More information on this site and the entire tall tower network can be found at: http://www.esrl.noaa.gov/gmd/ccgg/towers/.

Standard meteorological measurements are also made continuously at several levels $(10 \mathrm{~m}, 100 \mathrm{~m}$, and $300 \mathrm{~m}$, reported at $60 \mathrm{~s}, 60 \mathrm{~s}$, and $30 \mathrm{~s}$, respectively)) on the tower by the NOAA ESRL Physical Sciences Division (NOAA-PSD), including wind speed and direction, relative humidity, and temperature. We categorize each observation in our analysis according to wind direction (at $300 \mathrm{~m}$ ) to facilitate a discussion of two distinct emission source regions: the oil and gas industrial region to the north and east and the Denver metro region to the south. To do this, we define three wind sectors, consistent with those defined in the CFRPS: N/E $\left(345^{\circ}\right.$ to $\left.120^{\circ}\right), \mathrm{S}\left(120^{\circ}\right.$ to $\left.240^{\circ}\right)$, and $\mathrm{W}\left(240^{\circ}\right.$ to $\left.345^{\circ}\right)$. These wind sectors are illustrated in Fig. 1. Wind sector boundaries are defined based on an analysis of the $\mathrm{CH}_{4} / \mathrm{CO}_{2} \mathrm{ff}$ ratio variability with wind direction, which shows two distinct regimes for the $\mathrm{CH}_{4} / \mathrm{CO}_{2}$ ff ratio (see Sect. 3.2). Wind direction for each sample is determined using the mean wind direction over the 30 minutes immediately prior to sampling. Samples with mean wind speeds lower than $2.5 \mathrm{~m} \mathrm{~s}^{-1}$ over this time period are removed from any sector-specific analysis in this study, in order to reduce the number of samples carrying 


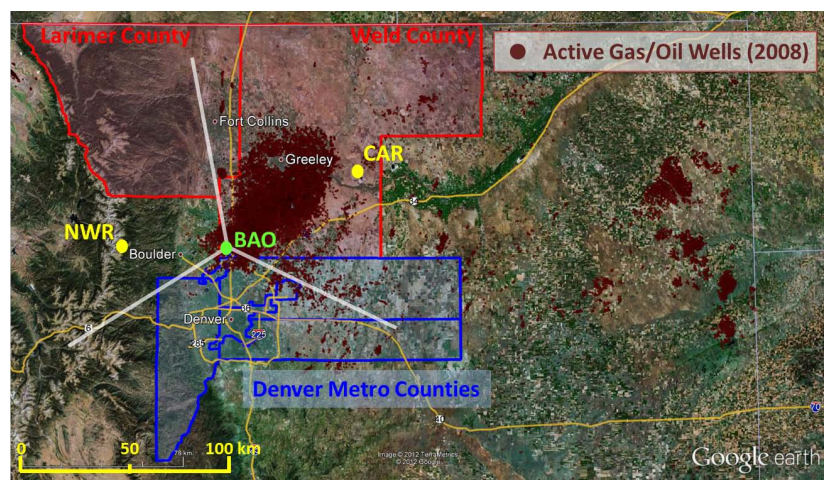

Fig. 1. Map of northeast Colorado showing the BAO tower and the distribution of active oil and gas wells as of 2008 (updated well locations available at: http://cogcc.state.co.us/Home/gismain. $\mathrm{cfm})$. Two background sites are also shown: Niwot Ridge (NWR; $3523 \mathrm{~m}$ a.s.1.) and the Briggsdale aircraft site (CAR). Also shown are the three wind sectors used to filter the dataset for emission estimates in Weld/Larimer counties (North and East) and in the Denver metro counties (South). The Denver metro counties include Denver, Broomfield, Adams, Arapahoe, and Jefferson. Top left corner of this map is: $41.064^{\circ} \mathrm{N}, 106.248^{\circ} \mathrm{W}$.

a disproportionate influence from sources in the immediate vicinity of the tower. Using a filter of greater than $2.5 \mathrm{~m} \mathrm{~s}^{-1}$ leaves too few samples for a rigorous statistical analysis of the data. Supplementary Figs. S1 and S2 show the time series of mean wind direction and wind speed, respectively, associated with each flask sample used in this analysis.

To define isotopic and mole fractions of trace gases in background air, measurements from two additional NOAAGMD sites were used. For ${ }^{14} \mathrm{CO}_{2}, \mathrm{CO}_{2}, \mathrm{CO}$, and $\mathrm{CH}_{4}$, we used weekly measurements from Niwot Ridge, $\mathrm{CO}$ (sitecode NWR, $40.05^{\circ} \mathrm{N}, 105.63^{\circ} \mathrm{W}, 3526 \mathrm{~m}$ a.s.l.), a site in the alpine tundra with strong westerly winds that only rarely required filtering of samples influenced by pollution from the Denver metro area (Turnbull et al., 2007). For other gases, including acetylene, benzene, and the $\mathrm{C}_{3}-\mathrm{C}_{5}$ alkanes we used weekly to fortnightly samples collected in the free troposphere from flights at a nearby location (3000 to $4000 \mathrm{~m}$ a.s.l. above Briggsdale Colorado; sitecode CAR, $40.37^{\circ} \mathrm{N}$, $104.30^{\circ} \mathrm{W}$, ground elevation $\sim 1700 \mathrm{~m}$ a.s.l.).

\subsection{Flask sampling}

Discrete whole air samples are collected daily (Andrews et al., 2013) from the BAO tall tower (from an air intake at $300 \mathrm{~m}$ ) using Programmable Flask Packages (PFPs) connected to a Programmable Compressor Package (PCP) capable of delivering 15 standard $\mathrm{L} \mathrm{min}^{-1}$. Each PFP contains 12 cylindrical borosilicate glass flasks $(0.7 \mathrm{~L}$ each). On each end of the flasks are automated glass-piston stopcocks, sealed with Teflon O-rings. Prior to deployment, each flask in the PFP unit is flushed with clean dry air and then pressurized to $\sim 140 \mathrm{kPa}$ with synthetic air containing $330 \mathrm{ppm} \mathrm{CO}_{2}$.
Automated sampling consists of the following steps: (1) a manifold flush, (2) a flask flush, and (4) pressurization of the flask to $\sim 270 \mathrm{kPa}$. The entire process takes about $2 \mathrm{~min}$. Sampled air at BAO first passes through a drying stage (dewpoint temperature at ambient pressure of $\sim 5^{\circ} \mathrm{C}$ ) prior to collection. Sampling is done at midday (19:30 UTC) in most cases; all samples used in this analysis were collected within $30 \mathrm{~min}$ of 19:30 UTC. Two flasks are filled within $5 \mathrm{~min}$ of each other ( $\sim 4$ standard liters) which provides enough air for analysis of the standard suite of trace gases (described below), and for analysis of ${ }^{14} \mathrm{CO}_{2}$, which typically requires 0.4 to $0.5 \mathrm{mg} \mathrm{C}$ for high precision $(<3 \%$ ) AMS analysis.

\subsection{Flask analysis}

Each flask pair is analyzed at NOAA-GMD for $\mathrm{CO}_{2}, \mathrm{CO}$, $\mathrm{CH}_{4}, \mathrm{SF}_{6}, \mathrm{H}_{2}, \mathrm{~N}_{2} \mathrm{O}$, and a suite of halocarbons and hydrocarbons. Stable isotopes of $\mathrm{CO}_{2}\left(\delta^{13} \mathrm{C}\right.$ and $\left.\delta^{18} \mathrm{O}\right)$ are analyzed at the INSTAAR Stable Isotope Laboratory (Vaughn et al., 2004). In this study, we use measurements of $\mathrm{CO}_{2}, \mathrm{CO}$, $\mathrm{CH}_{4}$, acetylene $\left(\mathrm{C}_{2} \mathrm{H}_{2}\right)$, benzene $\left(\mathrm{C}_{6} \mathrm{H}_{6}\right)$, propane $\left(\mathrm{C}_{3} \mathrm{H}_{8}\right)$, n-butane $\left(\mathrm{n}-\mathrm{C}_{4} \mathrm{H}_{10}\right)$, n-pentane $\left(\mathrm{n}-\mathrm{C}_{5} \mathrm{H}_{12}\right)$, and i-pentane (i$\mathrm{C}_{5} \mathrm{H}_{12}$ ). We also use $\delta^{13} \mathrm{C}$ in $\mathrm{CO}_{2}$ in the calculation of $\Delta{ }^{14} \mathrm{C}$, according to methods described by Stuiver and Polach (1977), which is required because the CAMS AMS does not measure the ${ }^{13} \mathrm{C} /{ }^{12} \mathrm{C}$ ratio on-line.

Dry air mole fractions of $\mathrm{CO}_{2}, \mathrm{CH}_{4}$, and $\mathrm{CO}$ were measured on one of two nearly-identical custom automated analytical systems. These systems consist of custom-made gas inlet systems, calibration systems, gas-specific analyzers, and system-control software. During this project, each system used a different technique to measure CO. One used a Reduction Gas Analyzer, where CO is separated from air by gas chromatography, then passed through a heated bed of $\mathrm{HgO}$ producing $\mathrm{Hg}$ before it is detected by resonance absorption (Novelli et al., 1998). The second is Vacuum UV Resonance Fluorescence (VURF), where CO is detected by fluorescence at $\sim 150 \mathrm{~nm}$. Both techniques are calibrated against the same standard scale, and uncertainties (68\% confidence interval) are $\sim 1 \mathrm{ppb}$ for the VURF and $\sim 2 \mathrm{ppb}$ for the RGA. Long-term comparison of the two systems shows agreement to within $\sim 1 \mathrm{ppb}$. $\mathrm{CH}_{4}$ was measured by gas chromatography (GC) with flame ionization detection with an uncertainty of $\sim 1.4 \mathrm{ppb}$ (Dlugokencky et al., 1994). A non-dispersive infrared analyzer is used for $\mathrm{CO}_{2}$ with an uncertainty $<0.1 \mathrm{ppm}$ (Conway et al., 1994).

The non-methane hydrocarbons $\left(\mathrm{C}_{2} \mathrm{H}_{2}\right.$, benzene, and $\mathrm{C}_{3}-$ $\mathrm{C}_{5}$ alkanes) are measured using a gas chromatographymass spectrometric (GC-MS) technique, with cryogenic preconcentration (Montzka et al., 1993; Miller et al., 2012). Measurement uncertainties for the hydrocarbons considered in this study vary by compound, and include known issues regarding (1) absolute calibration standard preparation errors, (2) the transfer of the absolute scale to the dry compressed whole air reference gases used in routine analyses, 
(3) uncertainty in assumed detector sensitivity due to analyte losses during random and sporadic temperature anomalies during the pre-concentration step, and (4) chromatographic baseline interferences (propane only). Storage tests have shown negligible drift in the hydrocarbon mole fractions of reference gases. Therefore, assigned total uncertainties $(1 \sigma)$ are $5 \%$ for $\mathrm{n}_{-} \mathrm{C}_{4} \mathrm{H}_{10}, \mathrm{i}-\mathrm{C}_{5} \mathrm{H}_{12}, \mathrm{n}_{-} \mathrm{C}_{5} \mathrm{H}_{12}$, and $\mathrm{C}_{6} \mathrm{H}_{6}$, and $15 \%$ for $\mathrm{C}_{3} \mathrm{H}_{8}$ due to chromatographic baseline interferences, and $15 \%$ for $\mathrm{C}_{2} \mathrm{H}_{2}$ due primarily to absolute calibration scale uncertainties. Measurement reproducibility $(1 \sigma)$ is generally $<2 \%$ for compounds present at mole fractions $>10$ ppt. For $\mathrm{C}_{2} \mathrm{H}_{2}$ and $\mathrm{C}_{3} \mathrm{H}_{8}$, the most volatile of these compounds, reproducibility was somewhat poorer during these flask analyses due to the instability of the temperature of the cryogenic pre-concentrator (approximately $-25 \%$ and $+12 \%$ ). The asymmetric reproducibility is attributed to the different impact that the temperature instability has on quantitation, depending on whether the anomalous temperature occurs during a BAO sample analysis or during analysis of the reference gas. This is primarily a problem only for the higher volatility species, $\mathrm{C}_{2} \mathrm{H}_{2}$ and $\mathrm{C}_{3} \mathrm{H}_{8}$. As this temperature instability is a random, sporadic occurrence, we conservatively allow for large negative uncertainties and smaller positive uncertainties in all analyses. An additional bias arising from non-linearity in the GC-MS response to varying analyte concentrations (except for propane, which is marginally linear) is estimated to result in an overestimate in the reported concentrations on the order of $5 \%$ to $12 \%$. We do not include this bias implicitly in our emission calculations, but we discuss its (minor) impact on our results and conclusions below.

All measurements are reported as dry air mole fractions relative to internally consistent standard scales maintained at NOAA-GMD. We use the following abbreviations for measured dry air mole fractions: $\mathrm{ppm}=\mu \mathrm{mol}$ (trace gas) $\mathrm{mol}$ $(\text { dry air })^{-1}, \mathrm{ppb}=\mathrm{nmol} \mathrm{mol}^{-1}$, and ppt $=\mathrm{pmol} \mathrm{mol}^{-1}$. Additional details on these methods are described at http://www. esrl.noaa.gov/gmd/ccgg/aircraft/analysis.html.

\subsection{Radiocarbon analysis}

A subset (typically 1 out of every 2 pairs) of the flask pairs are hand selected for analysis of ${ }^{14} \mathrm{CO}_{2}$. The selection is based on a visual inspection of continuous $\mathrm{CO}$ and $\mathrm{CO}_{2}$ observations during the time of sampling. For a typical flask package, 3 pairs (out of the 6 pairs total) are selected for radiocarbon analysis, with two pairs typically having the highest $\mathrm{CO}$ and $\mathrm{CO}_{2}$ concentrations and one pair having $\mathrm{CO}$ and $\mathrm{CO}_{2}$ concentrations closest to background. This approach maximizes the dynamic range of the observations over which tracer/ $\mathrm{CO}_{2} \mathrm{ff}$ ratios are estimated. Analyses of ${ }^{14} \mathrm{CO}_{2}$ were done by extracting $\mathrm{CO}_{2}$ from the whole air samples using cryogenic separation, reducing the extracted $\mathrm{CO}_{2}$ to graphite, and atom counting via accelerator mass spectrometry (AMS). Extractions of authentic samples, measurement controls, and process blanks were performed at the
University of Colorado INSTAAR Laboratory for AMS Radiocarbon Preparation and Research (NSRL) using an automated extraction system (Turnbull et al., 2010). Graphitization and AMS analysis was done at LLNL-CAMS. A description of the high precision methods for analysis of atmospheric samples at CAMS is given by Graven et al. (2007). The measurements are expressed as age-corrected $\Delta^{14} \mathrm{CO}_{2}$ in units of per mil (\%o), calculated from the ${ }^{14} \mathrm{C} /{ }^{13} \mathrm{C}$ ratio (normalized to a $\delta^{13} \mathrm{C}$ of $-25 \%$ ), measured relative to NBS Oxalic Acid I (OX1), and reported relative to the absolute radiocarbon standard, as detailed in Stuiver and Polach (1977). It should be noted that our use of $\Delta{ }^{14} \mathrm{CO}_{2}$, is equivalent to the use of $\Delta$ in Stuiver and Polach.

Uncertainty in these observations is assigned as the standard deviation $(1 \sigma)$ of a series of repeat measurements on extraction aliquots of whole air stored in high pressure cylinders. Air from two surveillance cylinders having different but near-ambient ${ }^{14} \mathrm{C}$ activities, identified as NWT3 and NWT4, were extracted, graphitized, and analyzed concurrent with the BAO samples across 7 different measurement "wheels" or batches. Multiple samples of NBS Oxalic Acid II (OX2, a commonly used secondary standard) were combusted, graphitized and analyzed simultaneously. Typically, in a wheel containing 25 authentic samples, 12 measurement controls and 1 process blank were analyzed. For the observations described in this study, the $(1 \sigma)$ repeatability (standard deviation) of NWT3 and NWT4 samples was $\pm 2.2 \%$ o $(n=140)$. AMS measurement uncertainty (based on counting statistics) typically contributes about $1.3-1.7 \%$ of the total uncertainty. In a small number of cases, the internal variability on the measurement of an unknown sample was larger than the repeatability of the pool of NWT samples. The larger of the two is assigned as the uncertainty for a given $\Delta{ }^{14} \mathrm{CO}_{2}$ measurement.

\subsection{Calculation of $\mathrm{CO}_{2} \mathrm{ff}$}

Recently added fossil fuel $\mathrm{CO}_{2}\left(\mathrm{CO}_{2} \mathrm{ff}\right)$ is defined as the local enhancement of $\mathrm{CO}_{2}$, with respect to an appropriate background reference site, due to fossil fuel emissions. $\mathrm{CO}_{2} \mathrm{ff}$ is estimated using a mass balance approach (Levin et al., $2003)$, in which the observed mole fraction of $\mathrm{CO}_{2}\left(\mathrm{CO}_{2} \mathrm{obs}\right)$ is partitioned into background $\mathrm{CO}_{2}\left(\mathrm{CO}_{2} \mathrm{bkg}\right)$, fossil $\mathrm{CO}_{2}$, and biogenic $\mathrm{CO}_{2}\left(\mathrm{CO}_{2}\right.$ bio $)$ components. $\mathrm{CO}_{2}$ bio is the net balance between respired $\mathrm{CO}_{2}\left(\mathrm{CO}_{2}\right.$ resp $)$ and $\mathrm{CO}_{2}$ taken up by photosynthesis $\left(\mathrm{CO}_{2}\right.$ photo). We further separate the respired fraction into autotrophic respiration $\left(\mathrm{CO}_{2}\right.$ auto $)$ and heterotrophic respiration $\left(\mathrm{CO}_{2}\right.$ het $)$ that originates from older soil carbon pools (which typically contain more bomb ${ }^{14} \mathrm{C}$ ). Equations (1a) and (1b) detail this mass balance relationship, as formulated in Turnbull et al. (2006), with $\mathrm{CO}_{2}$ resp separated into heterotrophic and autotrophic components. Similarly, an isotopic mass balance equation (Eq. 2) can describe the contribution of these three end members to the total 
observed $\Delta^{14} \mathrm{C}$.

$\mathrm{CO}_{2}$ obs $=\mathrm{CO}_{2} \mathrm{bkg}+\mathrm{CO}_{2} \mathrm{ff}+\mathrm{CO}_{2}$ bio

$\mathrm{CO}_{2}$ bio $=\mathrm{CO}_{2}$ auto $+\mathrm{CO}_{2}$ het $-\mathrm{CO}_{2}$ photo

$\Delta_{\text {obs }}^{14} \mathrm{CO}_{2} \mathrm{obs}=\Delta_{\text {bkg }}^{14} \mathrm{CO}_{2} \mathrm{bkg}+\Delta_{\text {ff }}^{14} \mathrm{CO}_{2} \mathrm{ff}+\Delta_{\text {bio }}^{14} \mathrm{CO}_{2}$ bio

Since $\Delta^{14} \mathrm{C}$ values are all normalized by their $\delta^{13} \mathrm{C}$ values, and thus are not influenced by natural fractionation, we can assume that $\Delta_{\text {photo }}^{14}$ and $\Delta_{\text {auto }}^{14}$ are identical to $\Delta_{\text {bkg }}^{14}$ (Turnbull et al., 2006). The system of equations can then be solved for $\mathrm{CO}_{2}$ ff to give Eq. (3).

$\mathrm{CO}_{2} \mathrm{ff}=\left(\frac{\mathrm{CO}_{2} \mathrm{obs}\left(\Delta_{\text {obs }}^{14}-\Delta_{\text {bkg }}^{14}\right)}{\left(\Delta_{\mathrm{ff}}^{14}-\Delta_{\text {bkg }}^{14}\right)}\right)-\left(\frac{\mathrm{CO}_{2} \text { het }\left(\Delta_{\text {het }}^{14}-\Delta_{\text {bkg }}^{14}\right)}{\left(\Delta_{\mathrm{ff}}^{14}-\Delta_{\text {bkg }}^{14}\right)}\right)$

In this equation, the variables in the first term are either known $\left(\Delta_{\mathrm{ff}}^{14}=-1000 \%\right)$ or can be measured. We use observations from NWR to estimate $\Delta_{\mathrm{bkg}}^{14}$. The background is estimated by applying a smoothing algorithm (Thoning et al., 1989) to the NWR data (a curve-fit of 3 polynomials, 4 harmonics, and added low-pass filtered residuals), after filtering out samples influenced by upslope flows carrying locally influenced air, characterized by high $\mathrm{CO} / \mathrm{CO}_{2}$ ratios, as in Turnbull et al. (2007). Smoothed NWR results used here are from Lehman et al. (2013). The standard deviation of the residuals from the smoothing fit are calculated to be $1.7 \%$. The selection of a proper background site is thought to introduce uncertainties on the order of the measurement uncertainty $(\sim 2 \%$ ) (Turnbull et al., 2009). We define the uncertainty in $\mathrm{CO}_{2} \mathrm{ff}$ as $1.2 \mathrm{ppm}$, estimated from the measurement uncertainty in $\Delta_{\text {bkg }}^{14}$ and $\Delta_{\text {obs }}^{14}( \pm 2.2 \% o)$.

The second term in Eq. (3) is a minor correction to the calculation of $\mathrm{CO}_{2} \mathrm{ff}$ due to heterotrophic respiration from soils, which can draw from carbon pools that are on the order of tens of years old, and thus reflect the higher $\Delta^{14} \mathrm{CO}_{2}$ in the atmosphere at the time. The magnitude of this correction can be estimated from a terrestrial ecosystem model, such as the CASA biogeochemical model (Thompson and Randerson, 1999); we follow the estimates of Turnbull et al. (2009) for North American mid-latitudes and set this correction to -0.2 $( \pm 0.1) \mathrm{ppm}$ (thus resulting in a positive offset) from October to March and to $-0.5( \pm 0.3) \mathrm{ppm}$ from April to September. Since the correction term in Eq. (3) is subtracted from the first term, the impact of heterotrophic respiration is to raise estimates of $\mathrm{CO}_{2} \mathrm{ff}$ in both seasons.

The influence of additional sources on $\Delta^{14}$ obs is globally variable and has potential contributions from stratospheric intrusion of cosmogenically produced and bomb-era ${ }^{14}$ C (e.g. Levin et al., 2010; Graven et al., 2012a), nuclear reactors (e.g. Graven and Gruber, 2011), biomass burning (e.g. Schuur et al., 2003; Vay et al., 2011), and the oceanicatmosphere disequilibrium (e.g. Sweeney et al., 2007; Muller et al., 2008). However, model-based estimates of the $\Delta^{14} \mathrm{C}$ signal (not including those from nuclear emissions) in the conterminous United States (Miller et al., 2012) show that these terms contribute very little relative to the spatial gradients arising from fossil fuel combustion. Graven and Gruber (2011) argue that in the eastern United States nuclear contributions may be significant, but they predict near-zero nuclear influence in most of the western United States, including Colorado. Any contribution from stratosphere or ocean sources at BAO is likely to simultaneously impact the NWR background site and, thus, can be ignored in this analysis. At least one sample was influenced by a biomass burning event, identified by an anomalously high $\mathrm{CO} / \mathrm{CO}_{2}$ ff ratio, as well as multiple news reports of poor air quality on that particular day resulting from the Station Fire in southern California in August 2009 (e.g. Brennan, 2009). This sample, along with one other that exhibits an abnormally high $\mathrm{CO} / \mathrm{CO}_{2} \mathrm{ff}$ ratio is omitted from this analysis. The sample influenced by the wildfire plume was collected 1 September 2009; the other sample, collected 30 January 2010, is unusual in that the estimated $\mathrm{CO}_{2}$ bio mole fraction (calculated as $\mathrm{CO}_{2} \mathrm{Obs}$ $-\mathrm{CO}_{2} \mathrm{ff}-\mathrm{CO}_{2} \mathrm{bkg}$ ) was very large ( $\left.15 \mathrm{ppm}\right)$, and about twice the estimated $\mathrm{CO}_{2} \mathrm{ff}$ for this sample. The large $\mathrm{CO}_{2}$ bio relative to other samples in the dataset suggests the possibility of an undetected stratospheric or biomass burning influence or an unusually large heterotrophic respiration signal. We therefore exclude this point (30 January 2010 sample) from our analysis. In addition to $\mathrm{CO}$, a large number of other anthropogenic tracers were elevated in this particular sample, suggesting that stratospheric influence is, in the end, not likely.

\subsection{Estimating tracer/ $\mathrm{CO}_{2}$ ff enhancement ratios}

Tracer/ $/ \mathrm{CO}_{2}$ ff enhancement ratios are calculated by taking the median of individual tracer/ $\mathrm{CO}_{2} \mathrm{ff}$ ratios after subtracting the background from each trace gas. The median ratios derived from individual samples provides a more robust estimate of the apparent tracer/ $\mathrm{CO}_{2} \mathrm{ff}$ ratios than that determined from either a linear regression slope or an arithmetic mean, which may give estimates that are overly sensitive to ratio outliers that can result from signals due to air masses in which emissions of various sources are not well mixed (Miller et al., 2012). While the linear regression method has the advantage of being less sensitive to the selection of background site, when considering observations across seasonal to annual time scales a seasonally varying background may still bias the slope determination. Since the BAO tower and the NWR and CAR background sites are closely situated, it is likely that any background-related biases are small. The tracer/ $\mathrm{CO}_{2} \mathrm{ff}$ ratios are shown in Table 1 . For comparison, estimates of slopes are also provided in Table 1 for each tracer/ $\mathrm{CO}_{2}$ ff pair, derived using a two-way least squares regression algorithm which estimates the geometric mean of the X-Y and Y-X regressions (without forcing the intercept through zero). Significant differences exist between the slopes and median ratios for many of the tracers, in particular for those with lower coefficients of determination 
Table 1. Summary of observed tracer/ $\mathrm{CO}_{2} \mathrm{ff}$ ratios and associated uncertainties. Ratios estimated using the median point-by-point calculation as well as from a two way linear regression. Correlation coefficients $\left(r^{2}\right)$ are also provided. For the $\mathrm{C}_{4}$ and $\mathrm{C}_{5}$ alkanes, $\mathrm{C}_{2} \mathrm{H}_{2}$, and benzene, a nonlinearity bias in the GC-MS response results in an estimated 5-12\% overestimate in the tracer/ $\mathrm{CO}_{2} \mathrm{ff}$ ratios for these gases.

\begin{tabular}{|c|c|c|c|c|c|c|c|c|c|c|c|c|}
\hline \multirow[t]{2}{*}{ Species } & \multirow[t]{2}{*}{ Wind Sector } & \multirow[t]{2}{*}{$n$} & \multicolumn{2}{|c|}{ Ratio (units) } & \multicolumn{2}{|c|}{$\begin{array}{l}\text { Ratio confidence } \\
\quad \text { limits }(2 \sigma)\end{array}$} & \multirow[t]{2}{*}{$n$} & \multicolumn{2}{|c|}{ Slope (units) } & \multicolumn{2}{|c|}{$\begin{array}{l}\text { Slope confidence } \\
\text { limits }(2 \sigma)\end{array}$} & \multirow[t]{2}{*}{$r^{2}$} \\
\hline & & & & & $\min$ & $\max$ & & & & $\min$ & $\max$ & \\
\hline \multirow[t]{3}{*}{$\mathrm{CO}$} & $\mathrm{N} / \mathrm{E}$ & 43 & 8.8 & $\left(\mathrm{ppb} \mathrm{ppm}^{-1}\right)$ & 7.3 & 9.4 & 55 & 8.5 & $\left(\mathrm{ppb} p \mathrm{pm}^{-1}\right)$ & 7.1 & 10.5 & 0.70 \\
\hline & $S$ & 22 & 10.5 & $\left(\mathrm{ppb} p p m^{-1}\right)$ & 7.3 & 13.8 & 31 & 7.2 & $\left(\mathrm{ppb} p \mathrm{pm}^{-1}\right)$ & 5.7 & 9.6 & 0.89 \\
\hline & Combined & 65 & 9.0 & $\left(\mathrm{ppb} \mathrm{ppm}^{-1}\right)$ & 8.1 & 9.8 & 86 & 7.8 & $\left(\mathrm{ppb} \mathrm{ppm}^{-1}\right)$ & 6.5 & 9.3 & 0.83 \\
\hline \multirow[t]{2}{*}{$\mathrm{CH}_{4}$} & N/E & 43 & 31.3 & $\left({\left.\mathrm{ppb} p p m^{-1}\right)}^{-1}\right.$ & 24.3 & 34.9 & 55 & 30.7 & $\left(\mathrm{ppb} p \mathrm{pm}^{-1}\right)$ & 22.1 & 34.5 & 0.81 \\
\hline & $S$ & 23 & 9.5 & $\left(\mathrm{ppb} \mathrm{ppm}^{-1}\right)$ & 5.8 & 12.4 & 33 & 8.1 & $\left(\mathrm{ppb} p \mathrm{pm}^{-1}\right)$ & 5.0 & 11.4 & 0.75 \\
\hline \multirow[t]{3}{*}{$\mathrm{C}_{2} \mathrm{H}_{2}$} & $\mathrm{~N} / \mathrm{E}$ & 41 & 44.5 & $\left(\mathrm{ppt} \mathrm{ppm}^{-1}\right)$ & 39.8 & 52.5 & 53 & 63.6 & $\left(\mathrm{ppt} \mathrm{ppm}^{-1}\right)$ & 37.6 & 73.5 & 0.81 \\
\hline & $S$ & 22 & 44.9 & $\left(\mathrm{ppt} \mathrm{ppm}^{-1}\right)$ & 34.7 & 61.6 & 32 & 45.2 & $\left(\right.$ ppt ppm $\left.{ }^{-1}\right)$ & 36.8 & 62.5 & 0.78 \\
\hline & Combined & 63 & 44.5 & $\left(\mathrm{ppt} \mathrm{ppm}^{-1}\right)$ & 40.7 & 51.8 & 85 & 52.1 & $\left(\mathrm{ppt} \mathrm{ppm}^{-1}\right)$ & 40.4 & 65.6 & 0.79 \\
\hline \multirow{2}{*}{ BENZ } & N/E & 41 & 29.0 & $\left(\mathrm{ppt} \mathrm{ppm}^{-1}\right)$ & 22.2 & 36.5 & 53 & 33.7 & $\left(\mathrm{ppt} \mathrm{ppm}^{-1}\right)$ & 21.9 & 38.7 & 0.81 \\
\hline & $\mathrm{S}$ & 22 & 19.8 & $\left(\mathrm{ppt} p \mathrm{pm}^{-1}\right)$ & 14.8 & 26.2 & 32 & 14.2 & $\left(\mathrm{ppt} p \mathrm{pm}^{-1}\right)$ & 10.7 & 19.8 & 0.72 \\
\hline \multirow[t]{2}{*}{$\mathrm{iC}_{5} \mathrm{H}_{12}$} & $\mathrm{~N} / \mathrm{E}$ & 41 & 277.5 & $\left(\mathrm{ppt} \mathrm{ppm}^{-1}\right)$ & 243.1 & 395.9 & 53 & 485.2 & $\left(\mathrm{ppt} \mathrm{ppm}^{-1}\right)$ & 297.9 & 565.1 & 0.75 \\
\hline & $S$ & 21 & 88.1 & $\left(p p t p^{-1}\right)$ & 47.6 & 120.7 & 31 & 65.4 & $\left(p p t p^{-1}\right)$ & 51.6 & 100.7 & 0.80 \\
\hline \multirow[t]{2}{*}{$\mathrm{nC}_{5} \mathrm{H}_{12}$} & $\mathrm{~N} / \mathrm{E}$ & 41 & 314.1 & $\left(\right.$ ppt ppm $\left.{ }^{-1}\right)$ & 236.8 & 402.4 & 53 & 480.6 & $\left(\mathrm{ppt} \mathrm{ppm}^{-1}\right)$ & 318.9 & 566.8 & 0.74 \\
\hline & S & 21 & 70.4 & $\left(\mathrm{ppt} \mathrm{ppm}^{-1}\right)$ & 37.4 & 106.0 & 31 & 54.5 & $\left(\mathrm{ppt} \mathrm{ppm}^{-1}\right)$ & 40.1 & 86.1 & 0.78 \\
\hline \multirow[t]{2}{*}{$\mathrm{nC}_{4} \mathrm{H}_{10}$} & $\mathrm{~N} / \mathrm{E}$ & 41 & 899.3 & $\left(\right.$ ppt ppm $\left.{ }^{-1}\right)$ & 707.9 & 1248.0 & 53 & 1520.8 & $\left(\right.$ ppt ppm $\left.{ }^{-1}\right)$ & 950.3 & 2085.1 & 0.71 \\
\hline & $\mathrm{S}$ & 21 & 193.3 & $\left(\mathrm{ppt} \mathrm{ppm}^{-1}\right)$ & 104.8 & 251.3 & 31 & 152.3 & $\left(\right.$ ppt ppm $\left.{ }^{-1}\right)$ & 102.6 & 212.8 & 0.75 \\
\hline \multirow[t]{2}{*}{$\mathrm{C}_{3} \mathrm{H}_{8}$} & $\mathrm{~N} / \mathrm{E}$ & 41 & 2035.2 & $\left(\mathrm{ppt} \mathrm{ppm}^{-1}\right)$ & 1615.8 & 2989.2 & 52 & 3265.1 & $\left(\mathrm{ppt} \mathrm{ppm}^{-1}\right)$ & 2048.4 & 4979.5 & 0.51 \\
\hline & $\mathrm{S}$ & 21 & 449.1 & $\left(\mathrm{ppt} \mathrm{ppm}^{-1}\right)$ & 243.3 & 612.1 & 31 & 352.7 & $\left(\mathrm{ppt} \mathrm{ppm}^{-1}\right)$ & 198.0 & 539.0 & 0.61 \\
\hline
\end{tabular}

$\left(r^{2}\right)$. Samples are only used in the median ratio calculation when the estimated $\mathrm{CO}_{2} \mathrm{ff}$ is above the $1.2 \mathrm{ppm} 1 \sigma$ detection limit to remove divide-by-zero errors, while no lower limit is used in the slope calculations. Removing this filter impacts the uncertainties of the median ratios (by up to $\sim 50 \%$ ), but it has a smaller impact on the median ratios themselves, typically impacting the tracer/ $\mathrm{CO}_{2} \mathrm{ff}$ ratios by less than $\pm 10 \%$, except for the $\mathrm{C}_{3}-\mathrm{C}_{5}$ alkanes in the $\mathrm{S}$ wind sector which are impacted by between +15 and $+30 \%$. In general, the application of this filter increases the enhancement ratios in the $\mathrm{S}$ wind sector and reduces them in the N/E wind sector. The supplementary material accompanying this manuscript includes figures (Figs. S3-S10) showing the data used to derive the median ratios, including time series and histograms of the dataset both with and without the wind speed and low $\mathrm{CO}_{2}$ ff cut-off filters.

Uncertainties in the median ratios are $95 \%$ confidence intervals, defined as the $2.5-97.5$ percentile range $(\sim 2 \sigma$ confidence) from a distribution of 500 estimates of the median from a randomized re-sampling of the data (boot-strapping with replacement). We also estimated the uncertainty in the tracer/ $/ \mathrm{CO}_{2} \mathrm{ff}$ enhancement ratios associated with measurement uncertainty (both for the trace gas and $\mathrm{CO}_{2} \mathrm{ff}$ ) and found that these uncertainties (at $2 \sigma$ ) were comparable to or lower than the boot-strap approach in all cases. For $\mathrm{C}_{2} \mathrm{H}_{2}$, $n-\mathrm{C}_{4} \mathrm{H}_{10}, n-\mathrm{C}_{5} \mathrm{H}_{12}, i-\mathrm{C}_{5} \mathrm{H}_{12}$, and $\mathrm{C}_{6} \mathrm{H}_{6}$, the nonlinearity in the GC-MS response results, potentially, in an additional overestimate in the tracer/ $/ \mathrm{CO}_{2}$ ff ratios for these gases of as much as $5-12 \%$. This bias has yet to be fully evaluated for each gas, and is therefore not incorporated into the reported enhancement ratios.

A measure of the appropriateness of the tracer/ $/ \mathrm{CO}_{2} \mathrm{ff}$ approach for deriving apparent emission ratios is estimated by calculating the $r^{2}$ from a linear regression of tracers vs. $\mathrm{CO}_{2}$ ff; a high $r^{2}$ suggests that emissions of the tracers are appreciably co-located with fossil fuel combustion sources. Results from the tracer/ $/ \mathrm{CO}_{2} \mathrm{ff}$ enhancement ratio calculations (with associated uncertainties, slopes, and $r^{2}$ values) are detailed in Table 1. Background observations for the different trace gases are taken from one of two nearby sites in the NOAA-GMD global network, either NWR $\left(\mathrm{CO}\right.$ and $\left.\mathrm{CH}_{4}\right)$ or from flights at CAR (acetylene, benzene, and the $\mathrm{C}_{3}-\mathrm{C}_{5}$ alkanes). $\mathrm{CO}$ and $\mathrm{CH}_{4}$ observations are available from both sites and we confirmed that the enhancement ratio estimates are not appreciably sensitive to the selection of background site (differences between $7 \%$ and $15 \%$ in derived enhancement ratios).

The sensitivity of this analysis to the prescribed heterotrophic respiration correction to $\mathrm{CO}_{2} \mathrm{ff}$ (Eq. 3) was determined by recalculating the tracer/ $\mathrm{CO}_{2} \mathrm{ff}$ ratios with this correction term doubled, in one case, and set to zero in another. The ratios estimated from this sensitivity test were within the $95 \%$ confidence intervals in all but two cases ( $\mathrm{CO}$ and $\mathrm{C}_{2} \mathrm{H}_{2}$ ), where the recalculated estimates were outside of the confidence intervals only by a few percent. Thus, we consider the uncertainty in the heterotrophic respiration correction to $\mathrm{CO}_{2}$ ff to be a largely insignificant source of error in our analysis. Given the relative lack of vegetation in the region 
Table 2. Summary of trace gas lifetimes and major emission sources influencing observations at BAO (Watson et al., 2001; Pétron et al., 2012).

\begin{tabular}{lll}
\hline Species & Atmospheric Lifetime & Major sources near BAO \\
\hline carbon monoxide $(\mathrm{CO})$ & 49 days & on-road and non-road gasoline combustion \\
methane $\left(\mathrm{CH}_{4}\right)$ & $6.9 \mathrm{yr}$ & oil and gas systems ${ }^{\mathrm{b}}$, waste water treatment, landfills, cattle feed lots \\
acetylene $\left(\mathrm{C}_{2} \mathrm{H}_{2}\right)$ & 17 days & mobile sources (combustion) \\
benzene $\left(\mathrm{C}_{6} \mathrm{H}_{6}\right)$ & 10 days & mobile sources (combustion and evaporative), oil and gas systems \\
iso-pentane $\left(i-\mathrm{C}_{5} \mathrm{H}_{12}\right)$ & 3.0 days & mobile sources (combustion and evaporative), oil and gas systems \\
n-pentane $\left(n-\mathrm{C}_{5} \mathrm{H}_{12}\right)$ & 3.1 days & oil and gas systems, mobile sources (combustion and evaporative) \\
n-butane $\left(n-\mathrm{C}_{4} \mathrm{H}_{10}\right)$ & 4.9 days & oil and gas systems \\
propane $\left(\mathrm{C}_{3} \mathrm{H}_{8}\right)$ & 12 days & oil and gas systems \\
$\mathrm{CO}_{2} \mathrm{ff}^{\mathrm{c}}$ & $\mathrm{N} / \mathrm{A}$ & on-road vehicles $(33 \%)$, electricity prod. $(32 \%)$, \\
& & residential $(11 \%)$, airborne $(10 \%)$, other $(14 \%)$ \\
\hline
\end{tabular}

\footnotetext{
a Atmospheric lifetimes estimated for $[\mathrm{OH}]=1 \times 10^{6} \mathrm{~cm}^{-3}$ using published rate constant data (Atkinson et al., 2006; NASA, 2006).

${ }^{\mathrm{b}}$ Sources include condensate tanks, well drilling and completion, distribution systems, refineries. ${ }^{\mathrm{c}}$ Source distribution according to Vulcan v2.2 for Weld/Larimer and Denver metro counties in 2008.
}

surrounding $\mathrm{BAO}$, it is more likely that the prescribed respiration correction is biased high rather than low, which would result in $\mathrm{CO}_{2} \mathrm{ff}$ values that are biased high and tracer/ $\mathrm{CO}_{2} \mathrm{ff}$ enhancement ratios that are biased low.

\subsection{Bottom-up fossil fuel $\mathrm{CO}_{2}$ emissions estimates}

To derive top-down emissions estimates for the observed trace gases via tracer/ $/ \mathrm{CO}_{2} \mathrm{ff}$ enhancement ratios, we use both county-level and gridded bottom-up fossil fuel $\mathrm{CO}_{2}$ emissions estimates from the Vulcan data product (v2.2) (Gurney et al., 2009) as a quantitative reference. Vulcan (http: //vulcan.project.asu.edu) is a high resolution data product that utilizes a combination of energy, air quality, census, traffic, and digital road statistics to quantify fossil fuel $\mathrm{CO}_{2}$ emissions for the United States. Until recently, the Vulcan inventory was available only for 2002, but is now updated to include annual emissions at the county and state level for all years between 1999 and 2008. The gridded high resolution product is currently available only for 2002, however. The Vulcan02 data product is used as the base year in this analysis. For the Vulcan02 product, country-wide emissions are in agreement with the United States Energy Information Administration (EIA) estimates to about $2 \%$ even though the different estimates were compiled using independent statistical datasets (Gurney et al., 2011). At the county level, the estimated uncertainty $(1 \sigma)$ on annual $\mathrm{CO}_{2} \mathrm{ff}$ emissions from the Vulcan02 data product is variable, but no more than $\sim 20 \%$ (and typically less than $\sim 10 \%$ ) for any given county (Gurney et al., 2011). To apply the Vulcan02 data product to our analysis period (2009-2010), the Vulcan02 emissions are scaled up to the observation period using the state-level EIA inventory (EIA, 2012), which is currently available through 2009. We use the county-level Vulcan data product for 2003-2008 to constrain the uncertainty in our scaling factor derived from the state-level EIA data. A more detailed description of the scaling procedure and associated uncertainty is provided below (Sect. 3.3).

Vulcan emission rates for $\mathrm{CO}_{2}$ are given in Table 3 for two source regions that correspond to the N/E and S wind sectors, as defined above (Sect. 2.6). For simplicity we define the N/E wind sector as being influenced primarily by emissions from Weld and Larimer Counties and the $\mathrm{S}$ wind sector as being influenced primarily by emissions from Adams, Broomfield, Arapahoe, Jefferson, and Denver Counties (collectively referred to here as the Denver metro counties). Total $\mathrm{CO}_{2} \mathrm{ff}$ emissions, according to Vulcan02, are estimated to be $2.94 \mathrm{TgC}$ and $7.27 \mathrm{TgC}$ for the N/E (Weld and Larimer Counties) and $\mathrm{S}$ (Denver metro counties) wind sectors, respectively. The on-road, electrical production, residential, and airborne sectors contribute to $86 \%$ of the total $\mathrm{CO}_{2} \mathrm{ff}$ emissions in the region (Table 2). In Sect. 3.3.1, we consider the uncertainties associated with these assumptions about the geographic area influencing emissions in the two wind sectors.

\subsection{Bottom-up trace gas emissions estimates}

We compare our top-down emission estimates with bottomup estimates for CO (NEI, 2008) and acetylene (NEI, 2005). Emissions of $\mathrm{C}_{2} \mathrm{H}_{2}$ are estimated from a gridded NEI05 inventory of total VOC emissions in combination with the EPA SPECIATE(v4.3) model (EPA, 2011).

Table 3 summarizes the bottom-up emission estimates, including the base-year for each inventory. Scaling factors $(\alpha)$ for the trace gases that relate the inventory base-year to the observation period are estimated from population statistics or additional factors. Scaling of the tracer inventories, which are related primarily to mobile emissions, is calculated in proportion to the rate of increase in population according to statistics from the US Census Bureau. The uncertainty limits for the scaled emissions are assigned as the base year estimates (i.e. no change in emissions) on the low end to an 
Table 3. Summary of top-down and bottom-up annual emissions for $\mathrm{CO}$ and $\mathrm{C}_{2} \mathrm{H}_{2}$, including the bottom-up emission source, inventory base year, the scaling term $(\alpha)$, and associated uncertainties derived for different regions around the sampling site in Colorado for the measurement period. Bottom-up emissions for $\mathrm{CO}_{2} \mathrm{ff}$ are also summarized. Uncertainties on the scaled bottom-up emissions and the top-down emissions are described in Sects. 3.3 and 3.3.1.

\begin{tabular}{|c|c|c|c|c|c|c|c|c|c|c|c|c|c|c|c|c|}
\hline \multirow[t]{2}{*}{ Species } & \multirow[t]{2}{*}{ Wind Sector } & \multicolumn{2}{|c|}{$\begin{array}{l}\text { Bottom-Up } \\
\text { Emissions }\end{array}$} & \multirow[t]{2}{*}{ Source } & \multirow[t]{2}{*}{$\begin{array}{l}\text { Base } \\
\text { Year }\end{array}$} & \multirow[t]{2}{*}{$\begin{array}{l}\alpha \\
(\%)\end{array}$} & \multicolumn{2}{|c|}{$\begin{array}{c}\alpha \\
\min / \max \end{array}$} & \multicolumn{2}{|c|}{$\begin{array}{l}\text { Scaled } \\
\text { Emissions }\end{array}$} & \multicolumn{2}{|c|}{$\begin{array}{l}\text { Scaled Emissions } \\
\text { Min/Max }\end{array}$} & \multicolumn{2}{|c|}{$\begin{array}{c}\text { Top-Down } \\
\text { Emissions }\left(\mathrm{E}_{\mathrm{X}}\right)\end{array}$} & \multicolumn{2}{|c|}{$\begin{array}{c}\mathrm{E}_{\mathrm{X}} \\
\operatorname{Min} / \mathrm{Max}\end{array}$} \\
\hline & & & & & & & $\min$ & $\max$ & & & $\min$ & $\max$ & & & $\min$ & $\max$ \\
\hline \multirow[t]{3}{*}{$\mathrm{CO}$} & N/E & 116.0 & $\mathrm{Gg}$ & NEI08 & 2008 & 3.6 & -10.5 & 11 & 120.1 & $\mathrm{Gg}$ & 103.8 & 128.4 & 62.4 & $\mathrm{Gg}$ & 46.0 & 75.5 \\
\hline & $\mathrm{S}$ & 362.1 & $\mathrm{Gg}$ & NEI08 & 2008 & 1.7 & -10.5 & 5 & 368.2 & $\mathrm{Gg}$ & 324.1 & 380.5 & 182.5 & $\mathrm{Gg}$ & 116.8 & 251.2 \\
\hline & Combined & 478.1 & $\mathrm{Gg}$ & NEI08 & 2008 & - & - & - & 488.3 & $\mathrm{Gg}$ & 427.9 & 508.9 & 221.1 & $\mathrm{Gg}$ & 171.0 & 269.5 \\
\hline \multirow[t]{3}{*}{$\mathrm{C}_{2} \mathrm{H}_{2}$} & N/E & 0.172 & $\mathrm{Gg}$ & NEI05 & 2005 & 11.6 & 0 & 35 & 0.192 & $\mathrm{Gg}$ & 0.172 & 0.232 & 0.291 & $\mathrm{Gg}$ & 0.225 & 0.369 \\
\hline & $\mathrm{S}$ & 0.544 & $\mathrm{Gg}$ & NEI05 & 2005 & 5.2 & 0 & 16 & 0.572 & $\mathrm{Gg}$ & 0.544 & 0.629 & 0.727 & $\mathrm{Gg}$ & 0.506 & 1.034 \\
\hline & Combined & 0.643 & $\mathrm{Gg}$ & NEI05 & 2005 & - & - & - & 0.764 & $\mathrm{Gg}$ & 0.716 & 0.861 & 1.011 & $\mathrm{Gg}$ & 0.791 & 1.273 \\
\hline \multirow[t]{2}{*}{$\mathrm{CO}_{2}$} & $\mathrm{~N} / \mathrm{E}$ & 2.94 & $\operatorname{Tg} \mathrm{C}$ & Vulcan2.2 & 2002 & 2.8 & - & - & 3.02 & $\operatorname{TgC}$ & 2.42 & 3.63 & - & - & - & - \\
\hline & $\mathrm{S}$ & 7.27 & $\operatorname{TgC}$ & Vulcan2.2 & 2002 & 2.8 & - & - & 7.47 & $\operatorname{TgC}$ & 5.98 & 8.97 & - & - & - & - \\
\hline
\end{tabular}

estimate using a scaling factor that is 3 times the population increase on the high end. An exception to this is for the uncertainty limits for $\mathrm{CO}$ emissions. There is evidence that on-road mobile $\mathrm{CO}$ emissions have decreased in many urban regions over the past $15-20 \mathrm{yr}$ despite large population increases, and in Denver, specifically, the CO-to-fuel burnt ratio was observed to have decreased at a rate of about $7 \%$ per year between 1999 and 2007 (Bishop and Stedman, 2008). Therefore, the bottom-up CO emissions uncertainty is bracketed at the low end by an emission rate corresponding to a decrease in emissions of $10.5 \%$ from 2008 (the inventory base year) to the observation period. We acknowledge that scaling up of these trace gas estimates using population statistics is an unconstrained approximation, and we have, therefore, assigned conservatively large uncertainties. It is important to note, however, that the inventory base year estimate is always within the uncertainty brackets of the scaled inventory values, thus allowing the reader to evaluate the top-down and bottom-up comparison independent of any scaling assumptions made here.

\section{Results and discussion}

\section{1 $\Delta^{14} \mathrm{C}$ and $\mathrm{CO}_{2} \mathrm{ff}$ time series}

The results of the ${ }^{14} \mathrm{CO}_{2}$ analyses are shown in Fig. 2a with values ranging from -19.4 to $50.5 \%$ o. The time series runs from late June 2009 to September 2010, overlapping with the observation period of the CFRPS, where observations (from the same set of flask samples) up through the spring of 2010 were included in their top-down emission calculations. Excursions of $\Delta^{14} \mathrm{CO}_{2}$ at BAO (relative to the NWR background site) towards lower values signify the addition of recently emitted fossil fuel $\mathrm{CO}_{2}$ to the sampled air mass. As described in Sect. 2.5, the $\mathrm{CO}_{2} \mathrm{ff}$ mole fraction can be quantified using Eq. (3), with an uncertainty of $1.2 \mathrm{ppm}$ based on propagation of the analytical uncertainty in $\Delta^{14} \mathrm{CO}_{2}$ for both $\Delta^{14}$ obs and $\Delta^{14} \mathrm{bkg}$ (the uncertainty in $\mathrm{CO}_{2}$ terms is

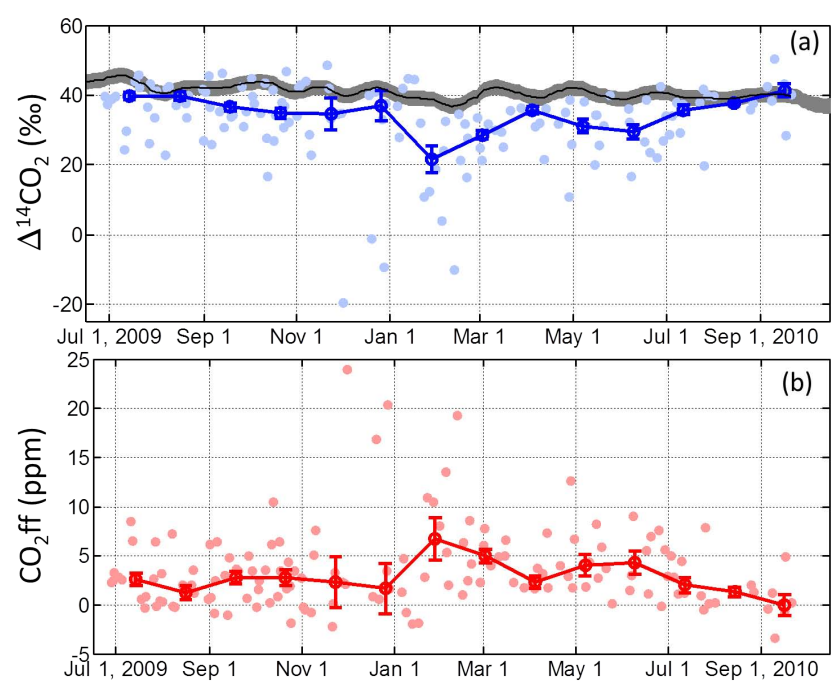

Fig. 2. Time series of ${ }^{14} \mathrm{CO}_{2}$ (a) and $\mathrm{CO}_{2} \mathrm{ff}$ (b) from 145 discrete whole air samples (filled circles) collected at the BAO tower. Uncertainty in each ${ }^{14} \mathrm{CO}_{2}$ measurement is $\pm 2.2 \%$, which translates to an uncertainty in each CO2ff observation of $1.2 \mathrm{ppm}$ (see Sect. 3.1). Thirty day binned medians are shown as open circles in both (a) and (b), with error bars representing the standard error of the mean $(1 \sigma)$ for each 30 day bin. Also shown in (a) is the ${ }^{14} \mathrm{CO}_{2}$ background as observed at NWR (black line) (Turnbull et al., 2007; Lehman et al.,2013), with the uncertainty envelope represented by the grey shaded region.

small relative to those for $\Delta^{14} \mathrm{C}$ ). Performing this calculation for each $\mathrm{BAO}$ observation in Fig. 2a gives $\mathrm{CO}_{2} \mathrm{ff}$ mole fractions that range from below the $1.2 \mathrm{ppm}$ detection limit up to $25 \mathrm{ppm}$. There are occasional instances of negative $\mathrm{CO}_{2} \mathrm{ff}$ values (14\% of all samples), which is not physically realistic. All but 5 of these samples ( $3 \%$ of the entire dataset) lie within the $1 \sigma$ envelope around zero and only 1 sample $(-3.3 \mathrm{ppm})$ lies outside of $2 \sigma$, thus these negative values are statistically consistent with $\mathrm{CO}_{2} \mathrm{ff}=0 \pm 1.2 \mathrm{ppm}$.

The most obvious feature of the $\mathrm{CO}_{2}$ ff variability is that mole fractions are high and variable in the winter months and 
relatively constant and lower, on average, during the summer months (Fig. 2b). This trend is qualitatively consistent with shallow, and variable, mixing layer heights in the winter and deep mixing layers in the summer (Turnbull et al., 2009). Mixing layer height is driven by a number of complex meteorological and topographical variables, but largely by surface sensible heat flux, which is of course much lower during the winter. Tracer/tracer ratios are expected to be much less sensitive to variability in mixing layer height since the dilution and mixing of co-located and temporally co-varying emissions will impact the different tracers equally. As we describe below, observations of a set of tracer/ $\mathrm{CO}_{2} \mathrm{ff}$ ratios are consistent with this expectation.

\subsection{Variability in tracer/ $\mathrm{CO}_{2}$ ff enhancement ratios}

When sources of trace gas emissions are co-located with fossil fuel combustion sources, an analysis of the trace gas enhancements relative to $\mathrm{CO}_{2} \mathrm{ff}$ provides a means to better understand the variability in the mix of emission sources influencing the site independent of the dilution and mixing dynamics that impact absolute mole fractions. While variability in the absolute mole fractions of $\mathrm{CO}_{2} \mathrm{ff}$ has a strong seasonal dependence (Fig. 2b), with larger enhancements observed in the winter than the summer, there is no apparent (statistically significant) seasonality to any of the considered tracer/ $\mathrm{CO}_{2} \mathrm{ff}$ enhancement ratios, suggesting that boundary layer dynamics are largely what are driving the seasonality in measured atmospheric mole fractions or that emissions of all the trace gases have similar seasonal cycles to $\mathrm{CO}_{2} \mathrm{ff}$.

Figure $3 \mathrm{a}$ and $\mathrm{b}$ show the dependence of the $\mathrm{CO} / \mathrm{CO}_{2} \mathrm{ff}$ and $\mathrm{CH}_{4} / \mathrm{CO}_{2} \mathrm{ff}$ enhancement ratios on wind direction using two different size wind direction bins $\left(40^{\circ}\right.$ and $\left.135^{\circ}\right)$, demonstrating a significant enhancement in $\mathrm{CH}_{4}$ abundance (relative to $\mathrm{CO}_{2} \mathrm{ff}$ ) when winds are arriving from the north and east of the $\mathrm{BAO}$ tower. The $\mathrm{CO} / \mathrm{CO}_{2} \mathrm{ff}$ ratio, on the other hand, is relatively constant with wind direction such that the uncertainties in the different sectors overlap, suggesting a consistent mix of $\mathrm{CO}$ and $\mathrm{CO}_{2} \mathrm{ff}$ combustion sources throughout the region. The $\mathrm{CH}_{4} / \mathrm{CO}_{2}$ ff variability with wind direction shows two distinct wind sectors within which the $\mathrm{CH}_{4} / \mathrm{CO}_{2}$ ff ratio is relatively stable. A significant drop-off in the $\mathrm{CH}_{4} / \mathrm{CO}_{2}$ ff ratio can be seen at around $\geq 115-120^{\circ}$, which corresponds to sectors having fewer oil and gas wells and stronger influence from the Denver metropolitan region. This provides the basis for the definition of the N/E and S wind sector boundaries, which we use to examine differences in emissions for each trace gas considered in the analysis that follows.

The variability in $\mathrm{CH}_{4} / \mathrm{CO}_{2}$ ff with wind direction is consistent with results presented in the CFRPS (Pétron et al., 2012), which found significantly enhanced mole fractions of alkanes, including $\mathrm{CH}_{4}, \mathrm{C}_{3} \mathrm{H}_{8}, \mathrm{n}-\mathrm{C}_{4} \mathrm{H}_{10}, i-\mathrm{C}_{5} \mathrm{H}_{12}$, and n$\mathrm{C}_{5} \mathrm{H}_{12}$, observed at $\mathrm{BAO}$ in air masses arriving from the N/E. Benzene was also enhanced in air masses arriving from the
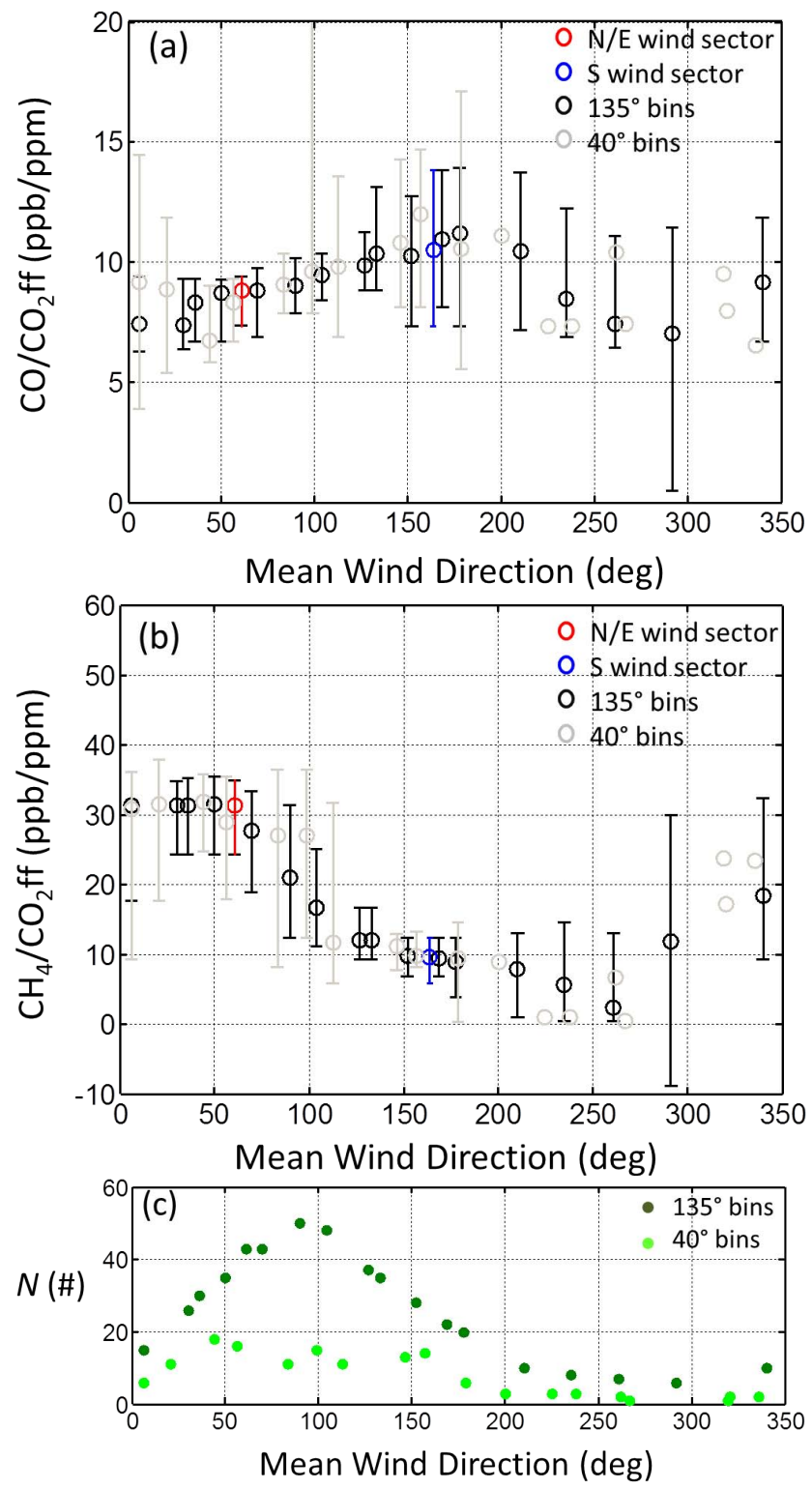

Fig. 3. Tracer/ $\mathrm{CO}_{2} \mathrm{ff}$ ratios as a function of mean wind direction for (a) $\mathrm{CO}$ and (b) $\mathrm{CH}_{4}$ for each rotating $135^{\circ}$-wide and $40^{\circ}$-wide wind sector wedge. The number of observations in each $135^{\circ}$ and $40^{\circ}$ wedge is shown in (c). Also shown are the tracer/ $/ \mathrm{CO}_{2} \mathrm{ff}$ ratios calculated for the N/E (red) and S (blue) wind sectors used in the analysis.

N/E. These differences were attributed to oil and gas production in Weld County, to the northeast of BAO. As shown on the map in Fig. 1, the majority of these wells are located in Weld County (COGCC, 2011), from which 17.9 million barrels of oil and 5.7 billion cubic meters of natural gas were produced in 2009 (COGCC, 2011). Other sources of $\mathrm{CH}_{4}$ in this region include cattle feedlots, landfills, waste water treatment plants, and natural gas processing plants. The transportation or mobile sector contributes significantly to a 
subset of the gases considered: $\mathrm{CO}, \mathrm{C}_{2} \mathrm{H}_{2}, \mathrm{C}_{6} \mathrm{H}_{6}, i-\mathrm{C}_{5} \mathrm{H}_{12}$, and, to a lesser extent, $n-\mathrm{C}_{5} \mathrm{H}_{12}$ (Watson et al., 2001). This sector likely contributes significantly to emissions from the Denver metro counties, but there are also significant mobile emissions in the N/E wind sector from Interstate 25, the main north-south route in Colorado, as well as in a number of population centers, including Fort Collins, all located due north of BAO, in Larimer County. Table 2 summarizes the expected sources of the trace gases evaluated in this analysis, along with their expected atmospheric lifetime with respect to oxidation by $\mathrm{OH}$. Lifetimes of the tracers considered range from 3 days (pentanes) to $7 \mathrm{yr}\left(\mathrm{CH}_{4}\right)$ (calculated with a constant $\mathrm{OH}$ density of $10^{6} \mathrm{~cm}^{-3}$ ). The oxidation of tracers can potentially reduce the observed enhancement ratio, lowering the apparent emission ratio. However, with no statistically significant seasonal differences for any of the tracer/ $/ \mathrm{CO}_{2} \mathrm{ff}$ ratios, we see no evidence of strongly seasonal $\mathrm{OH}$ chemistry impacting the tracer/ $\mathrm{CO}_{2} \mathrm{ff}$ ratios discussed here. This is likely a result of short transit times since emission relative to their atmospheric lifetimes.

\subsubsection{Carbon monoxide}

Figure 4a shows the relationship between $\mathrm{CO}$ enhancement and $\mathrm{CO}_{2} \mathrm{ff}$ for each sample. Fits of a linear regression are included in the Fig. 4a for the N/E and S wind sectors, giving $r^{2}$ values of $0.70(n=55)$ and $0.89(n=31)$, respectively. As detailed in Table 1, the point-by-point analysis of these observations show median (with $2 \sigma$ equivalent confidence intervals) $\mathrm{CO} / \mathrm{CO}_{2}$ ff enhancement ratios of 8.8 (7.3-9.4) and 10.5 (7.3-13.8) for the N/E and S wind directions, respectively. For all wind sectors combined, the median ratio is 9.0 $(8.1-9.8)\left(r^{2}=0.83\right)$.

A comparison of these $\mathrm{CO} / \mathrm{CO}_{2} \mathrm{ff}$ ratios with those found in other studies and those predicted by bottom-up inventories are shown in Fig. 5. The observed ratios from both wind sectors are similar to the values of $6.8 \pm 2.2$ and $11.7 \pm 5.5 \mathrm{ppb} \mathrm{ppm}^{-1}$ calculated at Niwot Ridge from two samples originating from the Boulder area via upslope winds in 2004 (Turnbull et al., 2006). Our estimates are somewhat lower, however, than previous reported values of $\mathrm{CO} / \mathrm{CO}_{2} \mathrm{ff}$ in Denver, where ratios were derived from linear correlations across 4 different aircraft flights ( $\sim 4-6$ samples per flight) in May and July of 2004 (Graven et al., 2009). The observed ratios from these flights ranged from $14-27 \mathrm{ppb} \mathrm{ppm}^{-1}$. Reductions in $\mathrm{CO}$ emissions from mobile sources between 2004 and 2009 are well documented (e.g. Bishop and Stedman, 2008) (part of a much longer term trend across most of the country), and could be a factor in the lower enhancement ratios observed here. The long term dataset from BAO, however, provides a more robust estimate of the $\mathrm{CO} / \mathrm{CO}_{2} \mathrm{ff}$ ratio than either of these short-term studies where small errors in individual data points could result in a large difference in the estimated ratio and where short term variability could have a strong influence. For comparison with these
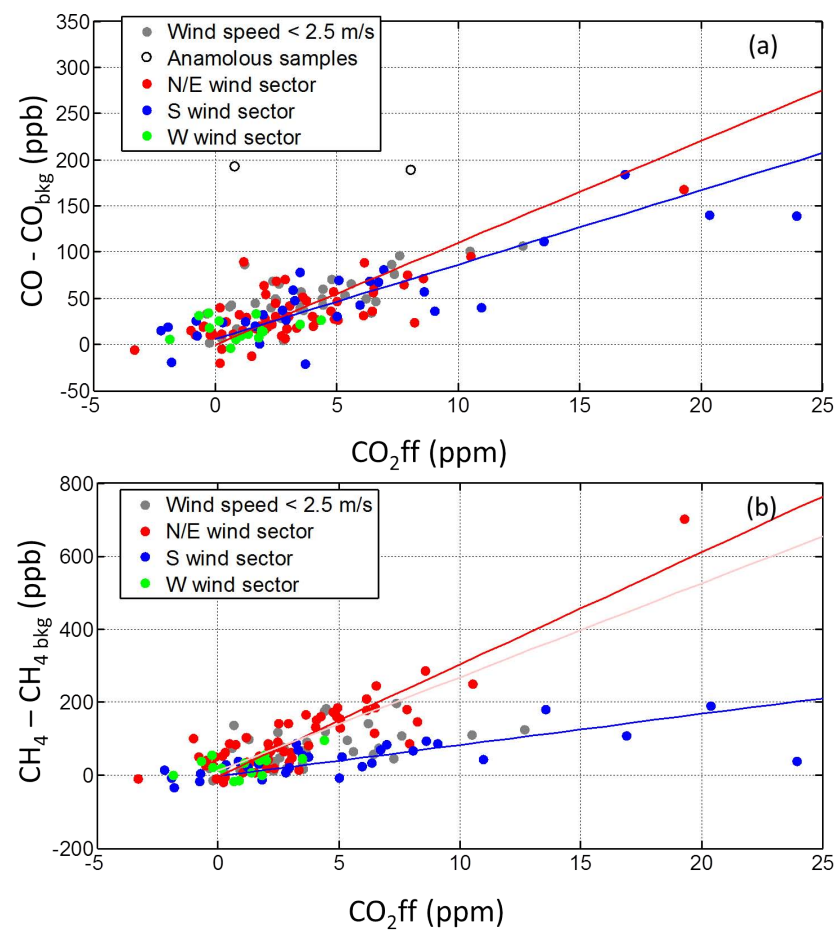

Fig. 4. Correlation plots of $\mathrm{CO}$ (a) and $\mathrm{CH}_{4}$ (b) enhancements (with respect to background observations) with $\mathrm{CO}_{2} \mathrm{ff}$. Data are separated into three wind sectors (north and east: red; south: blue; and west: green), except in cases where average wind speeds were below $2.5 \mathrm{~m} \mathrm{~s}^{-1}$ over the $30 \mathrm{~min}$ prior to sampling. Best-fit lines are shown for the N/E and S wind sectors (correlation coefficients are given in Table 1). In (a), two points are shown as open circles which are omitted from our analysis (see Sect. 2.5). In (b), a second bestfit line (light red) is shown for the N/E data, but excludes the highest $\mathrm{CO}_{2}$ ff sample.

short term datasets, observed ratios of $\mathrm{CO} / \mathrm{CO}_{2} \mathrm{ff}$ for individual samples from the south wind sector at $\mathrm{BAO}$ range from 3.6 to $13.5 \mathrm{ppb} \mathrm{ppm}^{-1}(1 \sigma)$, with a maximum observed value of $20 \mathrm{ppb} \mathrm{ppm}^{-1}$ (not including the sample impacted by biomass burning). Differences in the influencing area of emissions between the two studies may also play a role in the observed differences.

The main anthropogenic sources of $\mathrm{CO}$ in Colorado, and in much of the US, are from on-road gasoline vehicles in the mobile sector $(66 \%)$ and from non-road gasoline-based equipment (26\%) (NEI, 2008). While the on-road and nonroad sectors account for $92 \%$ of total CO emissions in Colorado, these sectors contribute only $29 \%$ of the total state $\mathrm{CO}_{2} \mathrm{ff}$ emissions according to the Vulcan08 data product (Gurney et al., 2009). Therefore, the remaining $71 \%$ of $\mathrm{CO}_{2}$ ff sources contributes to at most $8 \%$ of the total $\mathrm{CO}$ NEI emissions estimate in Colorado. This suggests that the average $\mathrm{CO} / \mathrm{CO}_{2} \mathrm{ff}$ emission ratio across a given region is expected to scale roughly with the fraction of $\mathrm{CO}_{2} \mathrm{ff}$ emissions coming from on-road and non-road combustion sources. 


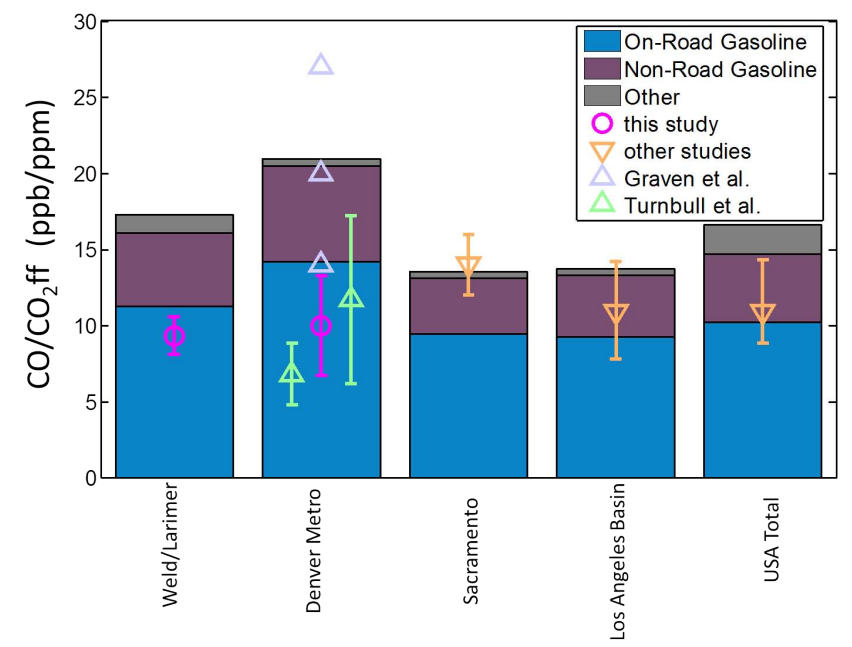

Fig. 5. A comparison of $\mathrm{CO} / \mathrm{CO}_{2} \mathrm{ff}$ ratios observed or estimated in various US locations. The bars are calculated from bottom-up emissions estimates (NEI08 CO and Vulcan2.2 $\mathrm{CO}_{2}$ ) and color-coded by the contribution of different sectors to the total $\mathrm{CO}$ emissions: on-road gasoline, non-road gasoline, and other. Observations from each location are shown, including those from our observations at BAO (split into Weld/Larimer and Denver metro influence based on wind sector) and observations from other studies: Denver (Turnbull et al., 2006; Graven et al., 2009)), Sacramento (Turnbull et al., 2011), LA Basin (which includes Los Angeles, Riverside, Orange, and San Bernardino counties) (Djuricin et al., 2010), and for the northeastern US (Miller et al., 2012).

Similar observed $\mathrm{CO} / \mathrm{CO}_{2} \mathrm{ff}$ ratios for both $\mathrm{N} / \mathrm{E}$ and $\mathrm{S}$ wind sectors, therefore, suggests a similar contribution of on-road and non-road $\mathrm{CO}_{2}$ ff sources in both Weld/Larimer counties and the Denver metro counties, consistent with the Vulcan data product which estimates that the on-road plus non-road sectors (the dominant CO contributors) combine for $29 \%$ and $41 \%$ of the total $\mathrm{CO}_{2}$ emissions, for Weld/Larimer and Denver metro area respectively (Gurney et al., 2009). This is in contrast to $\mathrm{CH}_{4}$ and other trace gases, as we discuss below, where there is a clear enhancement due to non-combustion sources related to oil and gas production in the N/E sector.

\subsubsection{Methane}

We find significant differences in the mole fraction enhancement of $\mathrm{CH}_{4}$ relative to $\mathrm{CO}_{2} \mathrm{ff}$ depending on wind direction (Fig. 4b). The ratio in air arriving from the N/E sector is 31.3 (24.3-34.9) $\mathrm{ppb} \mathrm{ppm}^{-1}$ and that for air traveling from the $\mathrm{S}$ wind sector is $9.5(5.8-12.4) \mathrm{ppb} \mathrm{ppm}^{-1}$. This higher enhancement ratio in the N/E wind sector can also be visualized in the correlation plot of $\mathrm{CH}_{4}$ enhancement with $\mathrm{CO}_{2} \mathrm{ff}$ (Fig. 4b), where filtering by wind sector results in two highly correlated relationships with different slopes. An $r^{2}$ of $0.81(n=55)$ and $0.75(n=33)$ is calculated for the N/E and $\mathrm{S}$ wind sectors, respectively. The high correlation in the $\mathrm{N} / \mathrm{E}$ wind sector is influenced by the sample at relatively high

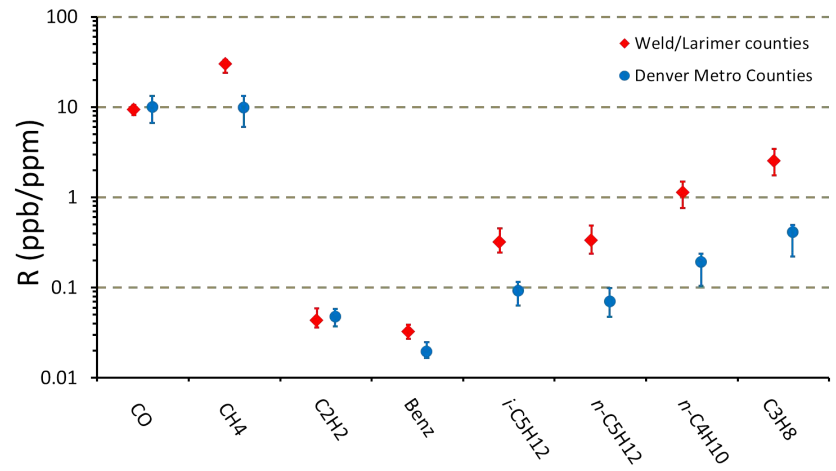

Fig. 6. Observed tracer/ $\mathrm{CO}_{2} \mathrm{ff}$ ratios from Weld County (N/E wind sector, red diamonds) and the Denver metro counties ( $\mathrm{S}$ wind sector, blue circles). Ratios are calculated as the median of the point-bypoint ratios for all data where $\mathrm{CO}_{2} \mathrm{ff}$ was detected above $1.2 \mathrm{ppm}$, as described in Sect. 3.3. Uncertainties in the median ratios are the $95 \%$ confidence intervals, defined as the $2.5-97.5$ percentile range ( $\sim 2 \sigma$ confidence) from a distribution of 500 median estimates from a randomized re-sampling of the data (boot-strapping with replacement). Note that the figure is presented using a logarithmic scale.

$\mathrm{CO}_{2} \mathrm{ff}\left(\sim 19 \mathrm{ppm} \mathrm{CO} \mathrm{CO}_{2} \mathrm{ff}\right)$; removing this single data point reduces the $r^{2}$ to 0.65 , but has little to no impact on the median enhancement ratio $\left(30.2(22.6-34.9) \mathrm{ppb} \mathrm{ppm}^{-1}\right)$. The median enhancement ratio is higher by a factor of 3 in the $\mathrm{N} / \mathrm{E}$ wind sector relative to the $\mathrm{S}$ wind sector, implying that emissions of $\mathrm{CH}_{4}$, relative to $\mathrm{CO}_{2} \mathrm{ff}$, are 3 times higher in the N/E sector than the $\mathrm{S}$ sector. The added source of $\mathrm{CH}_{4}$ influencing air samples arriving from the N/E likely results from a mix of emissions from oil and gas operations in the DJB (Pétron et al., 2012), and other non oil and gas sources, such as cattle feedlots.

Entrained $\mathrm{CO}_{2} \mathrm{ff}$ can be co-emitted from natural gas wells, but $\mathrm{CO}_{2}$ is only a small fraction ( $3-5 \%$ by mass) of raw natural gas (COGCC, 2011), and constitutes only a negligible fraction $(<0.1 \%)$ of total Weld/Larimer county $\mathrm{CO}_{2}$ emissions, based on the CFRPS estimates. This suggests that while emissions of $\mathrm{CH}_{4}$ and $\mathrm{CO}_{2}$ ff likely stem from separate processes, there is sufficient co-location of sources such that air mass mixing prior to sampling has led to good correlations between these two gases in the BAO record. Further evidence of this can be found in a consideration of multiple tracer $/ \mathrm{CO}_{2} \mathrm{ff}$ ratios, as discussed below.

\subsubsection{Other trace gases}

To further understand the differences in emission sources between the two wind sectors, we consider the tracer/ $/ \mathrm{CO}_{2} \mathrm{ff}$ ratios for a number of additional gases. Figure 6 shows the difference in median tracer/ $\mathrm{CO}_{2} \mathrm{ff}$ ratios for $\mathrm{CO}, \mathrm{C}_{2} \mathrm{H}_{2}$, $\mathrm{CH}_{4}, \mathrm{C}_{3}-\mathrm{C}_{5}$ alkanes, and benzene when winds are from the $\mathrm{N} / \mathrm{E}$ and $\mathrm{S}$ sectors. Like $\mathrm{CO}, \mathrm{C}_{2} \mathrm{H}_{2}$ is known to be emitted in industrialized and urban regions primarily from combustion sources (Whitby and Altwicker, 1978), while the 
other gases are emitted either from non-combustion sources $\left(\mathrm{C}_{3} \mathrm{H}_{8}, n-\mathrm{C}_{4} \mathrm{H}_{10}\right.$, and $\left.n-\mathrm{C}_{5} \mathrm{H}_{12}\right)$ or from a combination of sources $\left(\mathrm{C}_{6} \mathrm{H}_{6}\right.$ and i- $\left.\mathrm{C}_{5} \mathrm{H}_{12}\right)$. Both $\mathrm{CO}$ and $\mathrm{C}_{2} \mathrm{H}_{2}$ (relative to $\mathrm{CO}_{2} \mathrm{ff}$ ) show no appreciable dependence on wind direction in our data, suggesting that both gases are emitted primarily from combustion processes that are common to Weld/Larimer counties and the Denver metro counties. The median ratio of $\mathrm{C}_{2} \mathrm{H}_{2}$ enhancement to $\mathrm{CO}_{2} \mathrm{ff}$ observed at BAO (N/E and S combined) is $44.5(40.7-51.8) \mathrm{ppt} \mathrm{ppm}^{-1}$ (16th-84th percentile range) $\left(r^{2}=0.79, n=85\right)$, which is consistent with observations from two previous studies in different US locations: 52 (45-59) $\mathrm{ppt} \mathrm{ppm}^{-1}$ downwind of Sacramento, CA (Turnbull et al., 2011) and 45.9 (28.6102.9) $\mathrm{ppt} \mathrm{ppm}^{-1}$ off the east coast of the United States during winter (Miller et al., 2012). This consistency suggests a relative insensitivity of this ratio to a particular mix of emission type across the United States, an important criterion if one were to consider using $\mathrm{C}_{2} \mathrm{H}_{2}$ as a proxy for $\mathrm{CO}_{2} \mathrm{ff}$ in the absence of $\Delta^{14} \mathrm{CO}_{2}$ observations. However, the large spread observed in the enhancement ratio off the eastern US coast by Miller et al. (2012) (as reflected by the 16th and 84th percentiles of the distribution of observed ratios) suggests that there can be more variability in this ratio than indicated by the range of median values alone. Further, biomass burning can be a significant source of $\mathrm{C}_{2} \mathrm{H}_{2}$, likely impacting the $\mathrm{C}_{2} \mathrm{H}_{2} / \mathrm{CO}_{2}$ ff ratio in different regions at different times of year and from one year to the next. Additional research is required to better evaluate the potential for using $\mathrm{C}_{2} \mathrm{H}_{2}$ as a secondary $\mathrm{CO}_{2} \mathrm{ff}$ tracer and whether it would prove advantageous over the use of CO (Turnbull et al., 2006; Levin and Karstens, 2007), which may be problematic in locations where significant in situ CO production results from VOC oxidation.

As with $\mathrm{CH}_{4}$, there are significant differences in the tracer/ $\mathrm{CO}_{2} \mathrm{ff}$ enhancement ratios for the $\mathrm{C}_{3}-\mathrm{C}_{5}$ alkanes and benzene with wind direction, which suggests that enhanced emissions of these chemicals in the N/E are associated with gas and oil operations (Bar-Ilan et al., 2008a, b; Pétron et al., 2012). In general, ratios of $C_{3}-C_{5}$ alkanes are enhanced relative to $\mathrm{CO}_{2} \mathrm{ff}$ by about a factor of 4-5 in the N/E wind sector compared to the $\mathrm{S}$ wind sector. Benzene is enhanced in the N/E wind sector compared to the $S$ wind sector by a factor of 1.5. Despite the significant non-combustion sources of the VOCs related to gas and oil production, we see very good correlations of these species with $\mathrm{CO}_{2} \mathrm{ff}$ in air arriving from the N/E $\left(r^{2}>0.71\right.$, except for $\mathrm{C}_{3} \mathrm{H}_{8}$ for which $r^{2}=0.51$ and 0.61 for $\mathrm{N} / \mathrm{E}$ and $\mathrm{S}$, respectively) - an indication of integration of emissions by air mass mixing or substantial colocation of combustion sources with oil and gas operations. The enhancement of the alkane/ $\mathrm{CO}_{2} \mathrm{ff}$ ratios suggests, at least qualitatively, that a significant portion of the $\mathrm{CH}_{4}$ detected at BAO stems from activities related to the oil and gas industry (Pétron et al., 2012), since agricultural emissions of $\mathrm{CH}_{4}$ are not expected to be associated with emissions of $\mathrm{C}_{3}-\mathrm{C}_{5}$ alkanes.

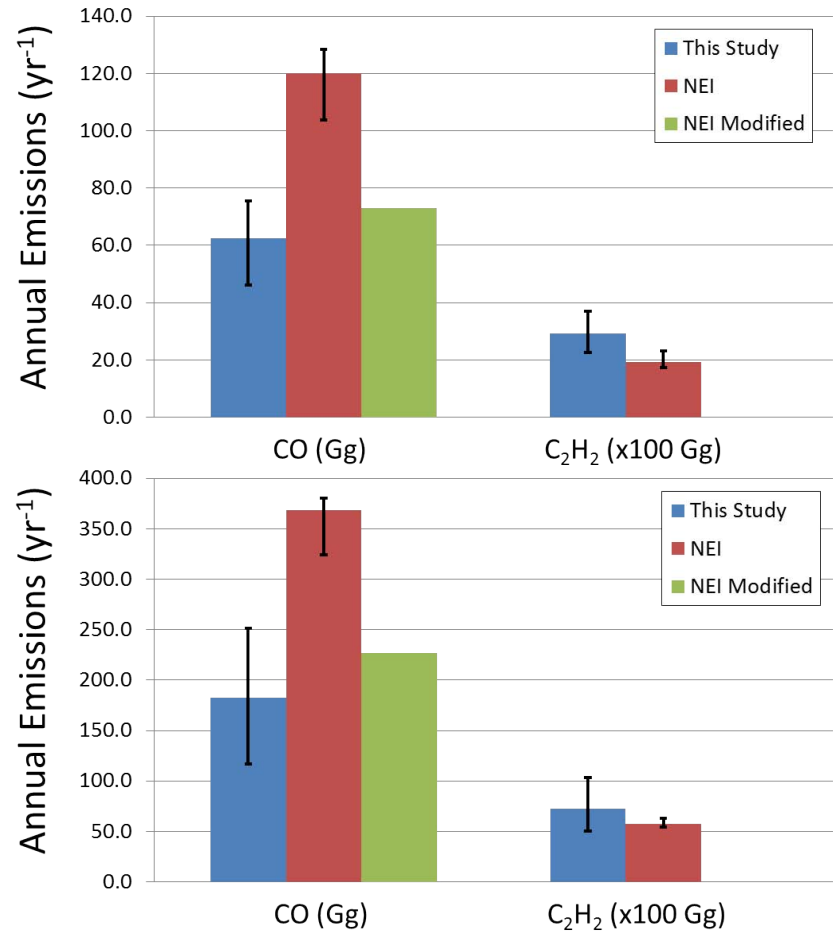

Fig. 7. Emissions estimates of $\mathrm{CO}$ and $\mathrm{C}_{2} \mathrm{H}_{2}$ from Weld/Larimer counties (top) and the Denver metro counties (bottom). Top-down emissions, calculated using Eq. (4), are shown as blue bars, with uncertainties given as described in Sect. 3.3. Bottom-up emissions estimates from the NEI (2005 for $\mathrm{C}_{2} \mathrm{H}_{2}$ and 2008 for $\mathrm{CO}$ ) inventory (red) are included for comparison for each species, as well as a modified bottom-up CO inventory as described in the text. Note the differences in units for the two trace gases.

\subsection{Estimating emission magnitudes}

From the observations described above as well as those reported in the CFRPS, it is clear that air sampled at the BAO tall tower is strongly influenced by emissions on local-toregional scales $\left(\sim 10^{3}-\sim 10^{5} \mathrm{~km}^{2}\right)$. Changes in wind direction at the site result in these local emissions coming from one of two primary source regions: (1) gas and oil operations to the north and east and (2) the Denver metro region to the south. Given the distinct geographical separation of sources, we use the wind sector specific observations, in conjunction with county-level $\mathrm{CO}_{2}$ emissions from the Vulcan data product (Gurney et al., 2009) as a means of estimating emissions for these trace gases using a tracer ratio approach.

$E_{\mathrm{X}}=E_{\mathrm{CO}_{2} \mathrm{ff}}(1+\alpha / 100) R$

Equation (4) describes the annual average top-down emissions for a series of trace gases $\left(E_{\mathrm{X}}\right)$. For reasons described below in Sect. 3.3.1, in this study we apply Eq. (4) to estimate emission magnitudes for $\mathrm{CO}$ and $\mathrm{C}_{2} \mathrm{H}_{2}$ only. In Eq. (4), $R$ is the median observed tracer/ $\mathrm{CO}_{2} \mathrm{ff}$ ratio, $E_{\mathrm{CO}_{2} \text { ff }}$ is the annual average Vulcan $\mathrm{CO}_{2} \mathrm{ff}$ emission rate for the region of 
interest, and $\alpha$ is a scaling factor that is designed to account for changes in emissions from the emission base year to the observation period. For $\mathrm{CO}_{2} \mathrm{ff}$ emissions, this factor is equal to the change in emissions (expressed as a \%) for the EIA inventory for Colorado between 2002 (the Vulcan base year) and the most current EIA inventory year, 2009. Equation (4) is applied independently to the N/E and S wind sectors for each tracer, with $R$ calculated for the $\mathrm{N} / \mathrm{E}$ and $\mathrm{S}$ wind sectors

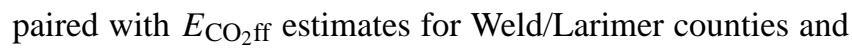
the metro Denver counties, respectively. Since $\alpha$ is based on state wide changes in $E_{\mathrm{CO}_{2} \mathrm{ff}}$, this scaling factor is equivalent for both wind sectors. Tracer/ $/ \mathrm{CO}_{2} \mathrm{ff}$ ratios $(R)$ are calculated as discussed in Sect. 3.2. Tables 1 and 3 summarize the parameters used to calculate $E_{\mathrm{X}}$ for Weld/Larimer counties and the Denver metro counties. Note that after applying the wind direction, wind speed, and low $\mathrm{CO}_{2}$ ff cut-off filters to the dataset there are more accepted measurements in the dataset during winter than summer, and thus any seasonal bias in the observed value $R$ would lead to winter emissions being overrepresented in the estimates of $E_{\mathrm{x}}$. From the available data, however, we can detect no significant differences (with respect to the $2 \sigma$ confidence intervals) in $R$ with season for the two gases considered. Additionally, we do not consider potential diurnal or day-of-week variability in emissions in this analysis. Since all the samples were collected at the same time of day - within 30 min of 12:30 local time, the derived emissions and emission ratios will be biased towards daytime (vs. nighttime) emissions. Weekends are slightly over sampled in this dataset (2.5 weekend samples for every 7 total samples) which could lead to a slight bias towards weekends in the annual emissions estimates; however, we do not find any statistically significant weekday-to-weekend differences in the tracer/ $/ \mathrm{CO}_{2} \mathrm{ff}$ ratios.

Uncertainties in $R$ (as described in Sect. 3.2), $E_{\mathrm{CO}_{2} \mathrm{ff}}$, and $\alpha$ are considered in the estimation of top-down emissions. The scaling term, $\alpha$, is $2.8 \%$ for the state of Colorado according to the EIA inventory. While this scaling term indicates almost no change between 2002 and 2009 emissions, in actuality, EIA emissions increased by $9 \%$ by 2007 and then decreased over the next $2 \mathrm{yr}$ (presumably related to the economic downturn in the United States during this period). Similar trends are observed in the county level Vulcan emissions over this time period, though the peak year in both Denver Metro and Weld/Larimer counties occurs earlier than 2007. Using changes in the annual EIA-based Colorado emissions to scale the Denver Metro and Weld/Larimer Vulcan02 estimates, gives, in general, very good agreement with the Vulcan estimates for these counties from 2003-2008 (to within $10 \%$ for any given year and about $5 \%$ on average). The Vulcan02 uncertainties $(1 \sigma)$ for the annual emission estimates from individual counties considered here are of similar order, ranging from $4.6 \%$ to $10.6 \%$, (K. Gurney, unpublished results) with less uncertainty associated with the combined larger county "sectors" that we use in our wind sector analysis. Doubling these uncertainties (to be consistent with our $2 \sigma$ analysis) for the two wind sectors results in differences from the central estimate of $7 \%$ (upper estimate) and $11 \%$ (lower estimate) for Weld/Larimer counties and $7 \%$ (upper) and $10 \%$ (lower) for the Denver metro counties. We therefore assign a conservative uncertainty of $\pm 20 \%$ to the scaled bottom-up $\mathrm{CO}_{2} \mathrm{ff}$ emissions estimates in this analysis, in which includes both uncertainty in both $E_{\mathrm{CO}_{2} \text { ff }}$ and $\alpha$.

It should be noted that the Vulcan estimates may include emissions of modern (non-fossil) $\mathrm{CO}_{2}$ from the on-road sector in locations where biofuels (ethanol) are used, including Colorado, which would lead to a positive bias in $E_{\mathrm{CO}_{2} \mathrm{ff}}$, and therefore, $E_{\mathrm{x}}$. This bias would scale directly with the fraction of total $\mathrm{CO}_{2} \mathrm{ff}$ (all sectors) in the Vulcan estimate that is from biofuels. For some perspective, a fleet-wide $15 \%$ biofuel blend in the on-road sector $\left(33 \%\right.$ of the total $\mathrm{CO}_{2} \mathrm{ff}$ emissions in the region; see Table 2) would result in a $+5 \%$ bias in our estimates of $E_{\mathrm{x}}$, which we consider small compared to other uncertainties. This would be roughly equivalent to assigning a value of $-950 \%$ o (rather than $-1000 \%$ ) for $\Delta_{\mathrm{ff}}^{14}$ in our derived $\mathrm{CO}_{2} \mathrm{ff}$ estimate.

The calculated top-down emission magnitude estimates $\left(E_{\mathrm{x}}\right)$ are given as a central estimate or 'best guess' for the annual emissions plus $95 \%$ confidence intervals calculated by propagation of the uncertainties described above. The bootstrap determination of uncertainties for the enhancement ratio provides a reasonable approximation of the impact of the variability of the tracer/ $/ \mathrm{CO}_{2}$ ff ratios. Figure 7 summarizes the top-down estimates and confidence intervals (whiskers), along with the available bottom-up estimates, for $\mathrm{CO}$ and $\mathrm{C}_{2} \mathrm{H}_{2}$ for each wind sector.

\subsubsection{Spatial considerations}

Additional uncertainty in $E_{\mathrm{CO}_{2} \mathrm{ff}}$ arises as a result of our assumptions regarding the geographic footprint (area of emissions) influencing the observations. Obviously, the emissions influencing the observations are not strictly confined to the county boundaries that we have selected, based on the simple wind sector analysis. This matters only to the extent that the spatial distribution of tracer/ $/ \mathrm{CO}_{2} \mathrm{ff}$ emission ratios varies between the presumed footprint and the actual footprint. This may be an issue especially for emissions estimates in the $\mathrm{N} / \mathrm{E}$ wind sector where we expect $\mathrm{VOC}$ and $\mathrm{CH}_{4}$ emissions from the DJB to be primarily confined to within Weld County while $\mathrm{CO}_{2}$ emissions are likely significant over a larger spatial scale. For example, there are significant $\mathrm{CO}_{2}$ emissions along the I-25 corridor (in Larimer County) to the north of $\mathrm{BAO}$, where there are relatively few active gas wells (see Fig. 1). Further, whereas $\mathrm{CO}_{2} \mathrm{ff}$ emissions are significant in both Weld $(55 \%)$ and Larimer (45\%) counties (according to Vulcan08), the vast majority $(\sim 99.8 \%)$ of natural gas and oil production (and, presumably, associated emissions) in the two counties is confined to Weld County (COGCC, 2011). Thus, the top-down emissions estimates of the trace gases from oil and gas production will be sensitive to our 
assumptions regarding the location and scale of areas influencing the observations: specifically, whether the observations are influenced by emission fluxes from southwest Weld County only or from a larger area that extends into the eastern part of Larimer County or other locations where $\mathrm{CO}_{2} \mathrm{ff}$ emissions are significant. Conversely, for $\mathrm{CO}$ and $\mathrm{C}_{2} \mathrm{H}_{2}$, the consistency in the enhancement ratio across all wind sectors supports the contention that the emissions estimates of these tracers are insensitive to presumptions about the precise area of emissions influencing the observations. Thus, we contend that the approach outlined above provides robust emission estimates for these two gases.

Because our analysis of trace gas emissions related to the oil and gas industry in the $\mathrm{N} / \mathrm{E}$ wind sector is expected to be sensitive to the uncertainty in the spatial footprint of observations, we refrain from estimating absolute emission rates for the trace gases related specifically to the oil and gas industry in Weld County $\left(\mathrm{CH}_{4}\right.$, benzene, and the $\mathrm{C}_{3}-\mathrm{C}_{5}$ alkanes). Reliable estimation of emissions from this critically important sector is a matter of ongoing research, using a variety of observational platforms. Improved transport models that can accurately represent and account for the unique topography and meteorology of the Colorado Front Range will also be required, whether using a tracer/tracer approach or inverse techniques. A more in depth study of the relationship between observed $\mathrm{CO}_{2} \mathrm{ff}$ at $\mathrm{BAO}$ and trace gases linked to the oil and gas sector is planned for a future publication.

\subsubsection{Carbon monoxide emission estimate}

We estimate annual CO emissions (shown in Fig. 7) to be 62.4 (46.0-75.5) $\mathrm{Gg} \mathrm{yr}^{-1} \mathrm{CO}$ for Weld/Larimer counties and 182.5 (116.8-251.2) $\mathrm{Gg} \mathrm{yr}^{-1} \mathrm{CO}$ for the metro Denver counties. The NEI08 estimates for these regions are $120.1 \mathrm{Gg} \mathrm{CO}$ and $368.2 \mathrm{Gg} \mathrm{yr}^{-1} \mathrm{CO}$, corresponding to overestimates by a factor of 1.9 and 2.0 for Weld/Larimer and metro Denver counties, respectively (Fig. 7). Our analysis indicates that total emissions for the two regions are overestimated by a factor of $2.2(1.8-2.9)$ in the NEI08 bottom-up inventory. These values are consistent with prior studies evaluating the accuracy of the NEI08 (and prior versions) CO emissions (Parrish, 2006; Hudman et al., 2008; Miller et al., 2008; Turnbull et al., 2011; Miller et al., 2012).

Comparing the results of different studies where radiocarbon observations were used to derive $\mathrm{CO} / \mathrm{CO}_{2} \mathrm{ff}$ ratios provides some insight into the ubiquity of the overestimate of $\mathrm{CO}$ emissions in the NEI inventory. A survey of observed $\mathrm{CO} / \mathrm{CO}_{2} \mathrm{ff}$ ratios from different locations, including Sacramento, CA (Turnbull et al., 2011), Denver (Turnbull et al., 2006; Graven et al., 2009), Irvine, CA (Djuricin et al., 2010), and off the eastern coast of the United States (Miller et al., 2012), reveals regional differences in the comparison between observations and bottom-up estimates (Fig. 5). The observations from the eastern seaboard of the United States point to an overestimate of NEI08 CO emissions (Miller et al., 2012), while both California-based studies find that the observed $\mathrm{CO} / \mathrm{CO}_{2} \mathrm{ff}$ ratio closely matches the estimates from California bottom-up inventories (Fig. 5). The Sacramento results were found to be in agreement with the California Air Resources Board (CARB) 2008 inventory, but the NEI05 inventory was high by about a factor of two (Turnbull et al., 2011). From our analysis, it appears as though this overestimate in the NEI inventory for California has been corrected in the 2008 release, perhaps a result of adopting the CARB estimates, as previously suggested by Turnbull et al. (2011). Similarly, the observations in Irvine (Djuricin et al., 2010) are in good agreement with the NEI08 inventory for the LA Basin (Los Angeles, Orange County, San Bernardino, and Riverside counties). From the BAO observations and those off the east coast of the US, it appears as though corrections were not made for the rest of the country.

As with the previous Denver observations, the Sacramento and Irvine observations are representative of shorter time periods: the Sacramento observations were compiled from linear correlations of 10 samples collected during 2 aircraft flights, while the Irvine observations were from 3 discrete samples collected over a few different months at a surface site on the campus of UC Irvine. The Miller et al. study provides a longer term average, similar to the BAO observations, but is more representative of northeast US regional-scale $\left(\sim 10^{5}-\sim 10^{6} \mathrm{~km}^{2}\right)$ sources rather than the local-to-regional $\left(\sim 10^{3}-\sim 10^{5} \mathrm{~km}^{2}\right)$ influence at BAO. Given the large differences in time and space scales relevant to each of these studies, the comparisons of $\mathrm{CO} / \mathrm{CO}_{2} \mathrm{ff}$ ratios in the various locations are not necessarily conclusive. However, as we will discuss in Sect. 4, we find that a closer inspection of the NEI08 inventory reveals a significant difference in the $\mathrm{CO}$ inventory in California vs. Colorado that is not supported by observations.

In situ production or loss of $\mathrm{CO}$ could also potentially bias these results. The most likely scenario would be the production of $\mathrm{CO}$ from the oxidation of VOCs by OH (Griffin et al., 2007) which can be significant in some locations, especially during summer when oxidation rates are intensified and biogenic VOC emissions are high (Turnbull et al., 2006). At BAO, we do not see an appreciable difference in the $\mathrm{CO} / \mathrm{CO}_{2} \mathrm{ff}$ ratio from winter to summer, which suggests little photochemical influence on $\mathrm{CO}$ abundance at $\mathrm{BAO}$. The atmospheric lifetime of $\mathrm{CO}$ is sufficiently long ( $\sim 50$ days) that consumption of $\mathrm{CO}$ by $\mathrm{OH}$ is also likely to be negligible in this analysis.

\subsubsection{Acetylene emission estimate}

Acetylene emissions are estimated to be 0.29 (0.23$0.37) \mathrm{Gg} \mathrm{yr}^{-1}$ in Weld/Larimer counties and 0.73 (0.511.0) $\mathrm{Gg} \mathrm{yr}^{-1}$ in the Denver Metro counties. These values are higher than the bottom-up estimates by factors of 1.5 $(1.2-1.9)$ and $1.3(0.9-1.8)$ for Weld/Larimer and Denver metro, respectively (Fig. 7). Nonlinearity issues with the 
$\mathrm{C}_{2} \mathrm{H}_{2}$ measurements may result in a positive bias for our emission estimates by as much as $12 \%$ (see Sect. 2.3), but this is not enough to bring the top-down and bottom-up estimates into agreement. In contrast to carbon monoxide, there has been very little evaluation of $\mathrm{C}_{2} \mathrm{H}_{2}$ emissions inventories in the United States. Warneke et al. (2007) compared the $\mathrm{C}_{2} \mathrm{H}_{2}$ : $\mathrm{CO}$ ratio from observations in Boston, New York, and Los Angeles to that in the NEI99 emissions database, and found the ratio to be underestimated in each location, suggesting a systematic underestimation of acetylene emissions by the NEI database. However, it is unclear whether this underestimation of the $\mathrm{C}_{2} \mathrm{H}_{2}$ : $\mathrm{CO}$ ratio is a result of an underestimate of $\mathrm{C}_{2} \mathrm{H}_{2}$ or an overestimate of $\mathrm{CO}$ (as detailed above). Using observations of ${ }^{14} \mathrm{CO}_{2}$, the $\mathrm{C}_{2} \mathrm{H}_{2}$ inventory can be evaluated independently of any biases in the $\mathrm{CO}$ emissions inventory. There have been two recent examples comparing top-down estimates of $\mathrm{C}_{2} \mathrm{H}_{2}$ emissions in the United States to bottom-up inventories using ${ }^{14} \mathrm{CO}_{2}$ observations: Miller et al. (2012) estimated $\mathrm{C}_{2} \mathrm{H}_{2}$ emissions for the entire United States (assuming northeast ratios were nationally representative) and found relatively good agreement (within $6 \%$ ) with the NEI05 $\mathrm{C}_{2} \mathrm{H}_{2}$ emissions inventory (the same gridded inventory used for comparison in this study and described above); Turnbull et al. (2011) published a comparison of $\mathrm{C}_{2} \mathrm{H}_{2}: \mathrm{CO}_{2}$ ff ratios from observations of the Sacramento urban plume with that calculated from bottom-up inventories and found $\mathrm{a} \sim 30 \%$ underestimate of $\mathrm{C}_{2} \mathrm{H}_{2}$ in the NEI05 inventory for Sacramento, CA. Both of these estimates, it should be noted, were made relative to the same $\mathrm{C}_{2} \mathrm{H}_{2}$ standard scale as in our estimates. Additional ${ }^{14} \mathrm{CO}_{2}$ observations co-measured with $\mathrm{C}_{2} \mathrm{H}_{2}$ in more locations and comparison with contemporaneous NEI05 values are required to come to any definitive conclusions regarding the accuracy of $\mathrm{C}_{2} \mathrm{H}_{2}$ emissions in the NEI05 database. The use of $\mathrm{C}_{2} \mathrm{H}_{2}$ as a secondary fossil fuel tracer or a proxy for $\mathrm{CO}_{2} \mathrm{ff}$ seems promising, however, given the limited evaluation of $\mathrm{C}_{2} \mathrm{H}_{2}$ emission sources in the literature as of today, further studies are recommended.

\section{Implications for Carbon Monoxide Inventory}

As discussed in Sect. 3.3.2, our observations and evaluation of the NEI08 inventory are consistent with prior findings that $\mathrm{CO}$ emissions are overestimated at the national level in previous versions of the NEI inventory (Parrish, 2006; Hudman et al., 2008; Miller et al., 2008). There is evidence, albeit from a limited number of samples, that the California countylevel bottom-up emissions of $\mathrm{CO}$ more accurately reflect the emissions estimated from atmospheric observations (Fig. 4). This provides the motivation to investigate whether there are fundamental differences in the methods for compiling the bottom-up CO inventory in California vs. Colorado, as well as in other states.
An analysis of the on-road sector $\mathrm{CO}$ (NEI08) and $\mathrm{CO}_{2} \mathrm{ff}$ (Vulcan08) emissions in comparison with the on-road observations of tail-pipe emissions of $\mathrm{CO}$ by Bishop and Stedman (2008) in Denver and Los Angeles (Fig. 8) suggests that NEI08 CO emissions in the on-road sector, specifically, are biased high in Colorado. These on-road observations show only very small differences between the CO:fuelburnt ratio (and therefore the $\mathrm{CO} / \mathrm{CO}_{2}$ ratio) emitted from vehicles in Denver (in 2006) and Los Angeles (in 2008). The CO:fuel-burnt ratios observed in the two cities correspond to $\mathrm{CO} / \mathrm{CO}_{2}$ emission ratios of $16 \mathrm{ppb} \mathrm{ppm}^{-1}$ (Denver in 2006) and $18 \mathrm{ppb} \mathrm{ppm}^{-1}$ (Los Angeles in 2006). In Los Angeles, the observed ratio (Bishop and Stedman, 2008) closely resembles the bottom-up ratio of $17 \mathrm{ppb} \mathrm{ppm}^{-1}$ calculated from the NEI08 and Vulcan08 inventories for the onroad sector only; however, the on-road sector bottom-up ratio (NEI08:Vulcan08) for Denver is $40 \mathrm{ppb} \mathrm{ppm}^{-1}$, which is 2.5 times the observed ratio (Bishop and Stedman, 2008). Similarly, in Weld/Larimer counties the bottom-up ratio is $43 \mathrm{ppb} \mathrm{ppm}^{-1}$ and US-wide it is $38 \mathrm{ppb} \mathrm{ppm}^{-1}$. It should be noted that the on-road $\mathrm{CO}$ emissions in California are estimated using a different mobile source model, EMFAC2007 (EMFAC, hereafter) (CARB, 2007) than that used for the rest of the United States, MOBILE6.2 (MOBILE, hereafter) (EPA, 2012b). In light of our comparison of $\mathrm{CO} / \mathrm{CO}_{2} \mathrm{ff}$ observations between California and other regions, and given the Bishop and Stedman (2008) observations in comparison with the on-road sector bottom up inventories, it appears likely that the MOBILE CO emission factor outputs are biased high relative to the EMFAC model.

This is also consistent with a recent comparison (Fujita et al., 2012) of these two mobile source models, along with the MOVES2010a (MOVES, hereafter) model, which was recently adopted by the EPA (EPA, 2010). This study showed that MOBILE emission factor outputs are biased high relative to the EMFAC and MOVES outputs, both of which showed close agreement with observations in a Los Angeles tunnel study. This analysis showed that $\mathrm{CO}$ was overestimated by the MOBILE model by a factor of 1.6-2.0 across a range of temperatures and traffic conditions and was found to be relatively insensitive to whether emission control programs were included in the model inputs. Both EMFAC and MOBILE use a region-wide average driving schedule and speed to compile emission factors for different vehicle types and model years, while MOVES uses a more specific approach, where emission factors are calculated for different speed and power bins. The consistency between MOVES, EMFAC, and the observations detailed in Fujita et al. (2012), suggests that the general framework of the MOBILE model for scaling up emission factors from individual vehicles for an average driving schedule, which is essentially the same as that used by the EMFAC model, is not the issue. Rather, the emission ratios associated with individual vehicle types and model years need to be adjusted. A separate study by the Federal Highway Administration Resource Center (Claggett 


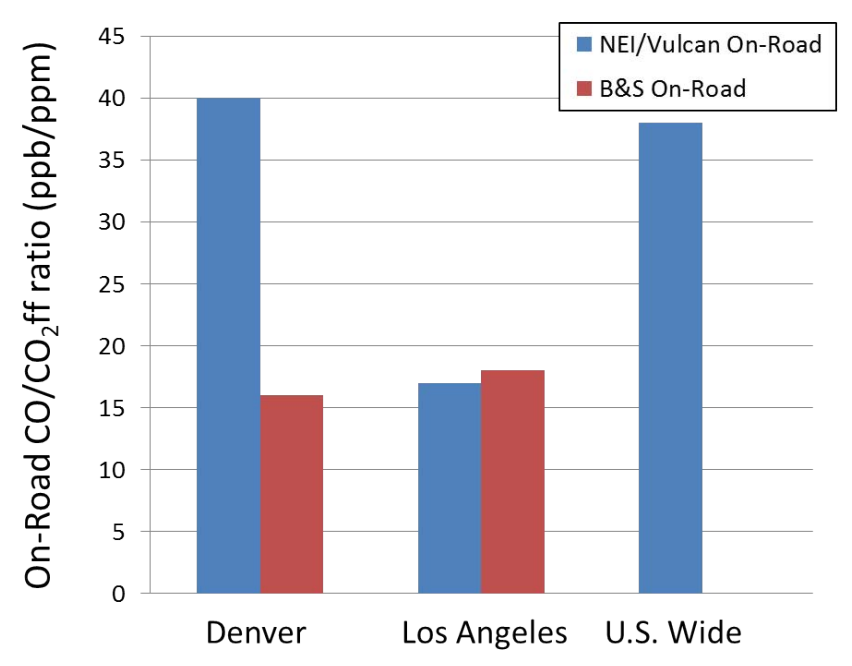

Fig. 8. On-road sector $\mathrm{CO} / \mathrm{CO}_{2}$ ff emission ratios derived from the tailpipe observations of Bishop and Stedman (2008) (B\&S, red) and from the sector-specific NEI08 $\mathrm{CO}$ and Vulcan $2.2 \mathrm{CO}_{2}$ emissions estimates (blue) for Denver, Los Angeles, and the US.

and Houk, 2008) also analyzed differences in emission factor outputs by the EMFAC and MOBILE models and found that across a spectrum of average vehicle speeds for identical vehicle fleets in 2010 (a future scenario in the 2008 study), the MOBILE model $\mathrm{CO}$ emission factors were higher than the EMFAC output by $50-300 \%$, depending on the average vehicle speed.

With the EPA soon to adopt MOVES2010a for the NEI, and given the analysis of Fujita et al. (2012), future releases of the NEI inventory can be expected to produce more accurate estimates of $\mathrm{CO}$ emissions for Colorado and the rest of the US. However, continued evaluations of these mobile source models should be performed alongside observations such as those presented here, as well as those from Bishop and Stedman (2008) and Fujita et al. (2012).

We derive a modified bottom-up CO estimate for the Denver metro counties and Weld/Larimer counties in which the NEI08 on-road sector CO emission rate is replaced with a new estimate calculated from the Vulcan08 on-road sector $\mathrm{CO}_{2}$ emission rate and the observed on-road sector $\mathrm{CO} / \mathrm{CO}_{2}$ ratio of $16 \mathrm{ppb} \mathrm{ppm}^{-1}$ from Bishop and Stedman (2008). This new estimate, shown in Fig. 7 and labeled as "Modified NEI", brings the top-down and bottom-up values to within $24 \%$ for the Denver metro counties and to within $18 \%$ for Weld/Larimer counties. The remaining discrepancy between these modified estimates and the observations could be a result of some combination of: (1) diesel vehicles that contribute significantly to the on-road sector $\mathrm{CO}_{2}$ emissions but are not a significant source of $\mathrm{CO}$; and (2) a reduction in the CO-to-fuel-burnt emission ratio between 2008 and 20092010. Additionally, this crude scaling exercise does not take into account changes in the $\mathrm{CO} / \mathrm{CO}_{2}$ emission ratio during "cold starts", which likely introduces significant variability at smaller spatial scales and shorter temporal scales. With these caveats acknowledged, scaling-up of this modified $\mathrm{CO}$ inventory reduces the total anthropogenic source of $\mathrm{CO}$ in the United States from $60 \mathrm{Tg} \mathrm{yr}^{-1}$ to $39 \mathrm{Tg} \mathrm{yr}^{-1}$, close to the $60 \%$ reduction suggested by Hudman et al. (2008) for anthropogenic $\mathrm{CO}$ emissions in the United States and close to the national ${ }^{14} \mathrm{CO}_{2}$ based estimate of $41(33-53) \mathrm{Tg} \mathrm{yr}^{-1}$ (Miller et al., 2012).

\section{Summary and conclusions}

We have analyzed 145 whole air samples for $\Delta^{14} \mathrm{CO}_{2}$ collected across 15 months at the NOAA BAO tall tower in Erie, Colorado. Air sampled at this site is heavily impacted by emissions from a variety of local sources including urban, rural, and industrial activities. The oil and gas industry, in particular, was found to contribute to enhancements in a number of industry-related trace gases relative to fossil fuel $\mathrm{CO}_{2}$ when the tower is downwind of oil and gas activities, which are concentrated in Weld County to the north and east of the sampling tower, although the relative contribution of other sources of $\mathrm{CH}_{4}$ in this sector were not determined. The observed enhancements suggest that emissions of $\mathrm{CH}_{4}$, $\mathrm{C}_{3}-\mathrm{C}_{5}$ alkanes, and benzene (relative to $\mathrm{CO}_{2}$ ff emissions) are a factor of $3, \sim 4-5$, and 1.5 greater, respectively, in air masses travelling from Weld and Larimer counties (north and east) over those originating from the Denver metro counties (south).

With the availability of a spatially resolved bottom-up $\mathrm{CO}_{2} \mathrm{ff}$ emissions data product from the Vulcan Project, we are able to take a tracer/tracer approach using $\mathrm{CO}_{2} \mathrm{ff}$, derived from $\Delta^{14} \mathrm{CO}_{2}$ observations, as a reference tracer, to critically evaluate the accuracy of the bottom-up emissions inventories for $\mathrm{CO}$ and $\mathrm{C}_{2} \mathrm{H}_{2}$. For these two gases, we find no significant differences in apparent emission ratio relative to $\mathrm{CO}_{2} \mathrm{ff}$ between the metro Denver region and Weld/Larimer counties, which suggests that top-down emissions estimates are largely insensitive to the assumptions about the sample footprint. We show that for both Weld/Larimer counties and the Denver metro counties, $\mathrm{C}_{2} \mathrm{H}_{2}$ is underestimated in the NEI05 inventory by a factor of about 0.66 while $\mathrm{CO}$ is overestimated in the NEI08 inventory by a factor of $\sim 2$. From the NEI08 $\mathrm{CO}$ and Vulcan08 $\mathrm{CO}_{2} \mathrm{ff}$ emissions estimates, we calculate that the average emission factor from on-road gasoline vehicles is $\sim 40 \mathrm{ppb} \mathrm{CO} \mathrm{ppm}^{-1} \mathrm{CO}_{2}$ for the region, while our observations suggest an emission ratio of $16 \mathrm{ppb} \mathrm{ppm}^{-1}$ for these vehicles.

For the trace gases originating from activities of the oil and gas industry to the north and east of the sampling tower, the primary barrier to estimating absolute emissions is the uncertainty in the spatial extent of the observation footprint, and therefore, the precise reference emissions value for $\mathrm{CO}_{2} \mathrm{ff}$. Weld and Larimer counties present an extreme case, in this regard, where emissions related to the oil and 
gas industry are confined to a well-defined region within a larger region of significant $\mathrm{CO}_{2} \mathrm{ff}$ emissions from mobile sources and where there is significant spatial heterogeneity in tracer/ $\mathrm{CO}_{2} \mathrm{ff}$ emission ratios. The incorporation of a reliable mesoscale atmospheric transport model into the analysis may allow for a more reliable estimation of absolute emissions for these gases. The increasing economic importance of the natural gas industry in the US and the uncertain climate and health ramifications provides strong motivation for a detailed study of the atmospheric transport in this region so that the $\Delta^{14} \mathrm{CO}_{2}$ observations at the BAO tower may be used to derive accurate emissions estimates of $\mathrm{CH}_{4}$.

\section{Supplementary material related to this article is available online at http://www.atmos-chem-phys.net/13/ 11101/2013/acp-13-11101-2013-supplement.pdf.}

Acknowledgements. The authors would like to acknowledge Paula Zermeño (CAMS), Shane Bradshaw (CAMS), and Chad Wolak (INSTAAR) for their contributions to ${ }^{14} \mathrm{CO}_{2}$ sample preparation, to C. Siso for analysis of the non-methane hydrocarbons, and to D. Kitzis for the preparation of the NWT reference cylinders. Funding was provided by DOE's Office of Biological and Environmental Research and NOAA. A portion of this work was performed under the auspices of the US Department of Energy by Lawrence Livermore National Laboratory under Contract DE-AC52-07NA27344.

Edited by: R. McLaren

\section{References}

Andres, R. J., Boden, T. A., Breon, F. M., Ciais, P., Davis, S., Erickson, D., Gregg, J. S., Jacobson, A., Marland, G., Miller, J., Oda, T., Olivier, J. G. J., Raupach, M. R., Rayner, P., and Treanton, K.: A synthesis of carbon dioxide emissions from fossil-fuel combustion, Biogeosciences, 9, 1845-1871, doi:10.5194/bg-9-18452012, 2012.

Andrews, A. E., Kofler, J. D., Trudeau, M. E., Williams, J. C., Neff, D. H., Masarie, K. A., Chao, D. Y., Kitzis, D. R., Novelli, P. C., Zhao, C. L., Dlugokencky, E. J., Lang, P. M., Crotwell, M. J., Fischer, M. L., Parker, M. J., Lee, J. T., Baumann, D. D., Desai, A. R., Stanier, C. O., de Wekker, S. F. J., Wolfe, D. E., Munger, J. W., and Tans, P. P.: $\mathrm{CO}_{2}, \mathrm{CO}$ and $\mathrm{CH}_{4}$ measurements from the NOAA Earth System Research Laboratory's Tall Tower Greenhouse Gas Observing Network: instrumentation, uncertainty analysis and recommendations for future highaccuracy greenhouse gas monitoring efforts, Atmos. Meas. Tech. Discuss., 6, 1461-1553, doi:10.5194/amtd-6-1461-2013, 2013.

Atkinson, R., Baulch, D. L., Cox, R. A., Crowley, J. N., Hampson, R. F., Hynes, R. G., Jenkin, M. E., Rossi, M. J., and Troe, J.: Evaluated kinetic and photochemical data for atmospheric chemistry: Volume II - gas phase reactions of organic species, Atmos. Chem. Phys., 6, 3625-4055, doi:10.5194/acp-6-3625-2006, 2006.
Bar-Ilan, A., Moore, T., Gribovicz, L., Sgamma, K., Pollack, A., and Henderer, D.: Development of baseline 2006 emissions from oil and gas activity in the Denver-Julesburg Basin, WRAP Phase III report http://www.wrapair.org/forums/ogwg/PhaseIII_Inventory. html, 34 pp., 2008a.

Bar-Ilan, A., Moore, T., Gribovicz, L., Sgamma, K., Pollack, A., and Henderer, D.: Development of 2010 oil and gas emissions projections for the Denver-Julesburg Basin, WRAP Phase III report http://www.wrapair.org/forums/ogwg/PhaseIII_Inventory. html, 26 pp., 2008b.

Bishop, G. A. and Stedman, D. H.: A decade of on-road emissions measurements, Environ. Sci. Technol., 42, 1651-1656, 2008.

Brennan, P. J.: Los Angeles Wildfire Sends Pollution as Far as Denver, Bloomberg, http://www.bloomberg.com/apps/news? pid=_newsarchive\&sid=_aJrSkTFs1dL4, (last access: 2009), 2009.

California Air Resources Board Mobile Sources Emissions Inventory, available at: http://www.arb.ca.gov/msei/onroad/latest_ version.htm (last access: 10 October 2012), 2007.

Claggett, M. and Houk, J.: Comparing MOBILE6.2 and EMFAC2007 Emission Factors, Transp. Res. Record, 51-57, doi:10.3141/2058-07, 2008.

COGCC: Colorado Oil and Gas Information System Data Base accessible at http://cogcc.state.co.us (last access: 14 June 2011), 2011.

Conway, T. J., Tans, P. P., Waterman, L. S., and Thoning, K. W.: Evidence for Interannual Variability of the Carbon-Cycle from the National-Oceanic-and-Atmospheric-Administration Climate-Monitoring-and-Diagnostics-Laboratory Global-AirSampling-Network, J. Geophys. Res. Atmos., 99, 22831-22855, 1994.

Currie, K. I., Brailsford, G., Nichol, S., Gomez, A., Sparks, R., Lassey, K. R., and Riedel, K.: Tropospheric $\left(\mathrm{CO}_{2}\right)-\mathrm{C}_{14}$ at Wellington, New Zealand: the world's longest record, Biogeochem., 104, 5-22, 2011.

Djuricin, S., Pataki, D. E., and Xu, X. M.: A comparison of tracer methods for quantifying $\mathrm{CO}_{2}$ sources in an urban region, J. Geophys. Res.-Atmos., 115, D11303, doi:10.1029/2009JD012236, 2010.

Dlugokencky, E. J., Steele, L. P., Lang, P. M., and Masarie, K. A.: The Growth-Rate and Distribution of Atmospheric Methane, J. Geophys. Res. Atmos., 99, 17021-17043, 1994.

EPA: Official release of the MOVES2010 motor vehicle emissions model for emission inventories in SIPs and tranportation conformity, Fed. Regist., 75, 9411-9414, 2010.

EPA: Speciate Software Download Site: http://www.epa.gov/ ttnchie1/software/speciate/ (last access: 19 June 2012), 2011.

EPA: MOBILE6 Vehicle Emission Modeling Software: http://www. epa.gov/oms/m6.htm (last access: 10 October 2012), 2012.

Fujita, E. M., Campbell, D. E., Zielinska, B., Chow, J. C., Lindhjem, C. E., DenBleyker, G. A., Bishop, G. A., Schuchmann, B. G., Stedman, D. H., and Lawson, D. R.: Comparison of the MOVES2010a, MOBILE6.2, and EMFAC2007 mobile source emission models with on-road traffic tunnel and remote sensing measurements, J. Air Waste Manage. Assoc., 62, 1134-1149, doi:10.1080/10962247.2012.699016, 2012.

Godwin, H.: Half-Life of Radiocarbon, Nature, 195, 984, doi:10.1038/195984a0, 1962. 
Graven, H. D. and Gruber, N.: Continental-scale enrichment of atmospheric ${ }^{14} \mathrm{CO}_{2}$ from the nuclear power industry: potential impact on the estimation of fossil fuel-derived $\mathrm{CO}_{2}$, Atmos. Chem. Phys., 11, 12339-12349, doi:10.5194/acp-11-12339-2011, 2011.

Graven, H. D., Guilderson, T. P., and Keeling, R. F.: Methods for high-precision $\mathrm{C}_{14}$ AMS measurement of atmospheric $\mathrm{CO}_{2}$ at LLNL, Radiocarbon, 49, 349-356, 2007.

Graven, H. D., Stephens, B. B., Guilderson, T. P., Campos, T. L., Schimel, D. S., Campbell, J. E., and Keeling, R. F.: Vertical profiles of biospheric and fossil fuel-derived $\mathrm{CO}_{2}$ and fossil fuel $\mathrm{CO}_{2}$ : CO ratios from airborne measurements of Delta(14)C, $\mathrm{CO}_{2}$ and CO above Colorado, USA, Tellus B, 61, 536-546, 2009.

Graven, H. D., Guilderson, T. P., and Keeling, R. F.: Observations of radiocarbon in $\mathrm{CO}_{2}$ at seven global sampling sites in the Scripps flask network: Analysis of spatial gradients and seasonal cycles J. Geophys. Res., 117, D02303, doi:10.1029/2011JD016535, 2012a.

Graven, H. D., Guilderson, T. P., and Keeling, R. F.: Observations of radiocarbon in $\mathrm{CO}_{2}$ at La Jolla, California, USA 1992-2007: Analysis of the long-term trend, J. Geophys. Res., 117, D02302, doi:10.1029/2011JD016533, 2012b.

Griffin, R. J., Chen, J. J., Carmody, K., Vutukuru, S., and Dabdub, D.: Contribution of gas phase oxidation of volatile organic compounds to atmospheric carbon monoxide levels in two areas of the United States, J. Geophys. Res.-Atmos., 112, D10S17, doi:10.1029/2006jd007602, 2007.

Gurney, K. R., Mendoza, D. L., Zhou, Y. Y., Fischer, M. L., Miller, C. C., Geethakumar, S., and Du Can, S. D.: High Resolution Fossil Fuel Combustion $\mathrm{CO}_{2}$ Emission Fluxes for the United States, Environ. Sci. Technol., 43, 5535-5541, 2009.

Gurney, K. R., Chandrasekaran, V., Mendoza, D. L., and Geethakumar, S.: Quantification of uncertainty associated with NACP high resolution fossil fuel $\mathrm{CO}_{2}$ emissions: updates, challenges and future plans, North American Carbon Program All-Inverstigators Meeting, New Orleans, LA, available at: http://www.nacarbon.org/meeting_ab_presentations/2011/2011_ Feb03_AM_Gurney_63.ppt, last access: 18 October 2013, 2011.

Hsueh, D. Y., Krakauer, N. Y., Randerson, J. T., Xu, X. M., Trumbore, S. E., and Southon, J. R.: Regional patterns of radiocarbon and fossil fuel-derived $\mathrm{CO}_{2}$ in surface air across North America, Geophys. Res. Lett., 34, L02816, doi:10.1029/2006GL027032, 2007.

Hudman, R. C., Jacob, D. J., Cooper, O. R., Evans, M. J., Heald, C. L., Park, R. J., Fehsenfeld, F., Flocke, F., Holloway, J., Hubler, G., Kita, K., Koike, M., Kondo, Y., Neuman, A., Nowak, J., Oltmans, S., Parrish, D., Roberts, J. M., and Ryerson, T.: Ozone production in transpacific Asian pollution plumes and implications for ozone air quality in California, J. Geophys. Res., 109, D23S10, doi:10.1029/2004JD004974, 2004.

Hudman, R. C., Murray, L. T., Jacob, D. J., Millet, D. B., Turquety, S., Wu, S., Blake, D. R., Goldstein, A. H., Holloway, J., and Sachse, G. W.: Biogenic versus anthropogenic sources of CO in the United States, Geophys. Res. Lett., 35, L04801, doi:10.1029/2007GL032393, 2008.

Lee, B. H., Munger, J. W., Wofsy, S. C., and Goldstein, A. H.: Anthropogenic emissions of nonmethane hydrocarbons in the northeastern United States: Measured seasonal variations from 19921996 and 1999-2001, J. Geophys. Res.-Atmos., 111, D20307, doi:10.1029/2005JD006172, 2006.
Lehman, S. J., Miller, J. B., Wolak, C., Southon, J., Tans, P. P., Montzka, S. A., Sweeney, C., Andrews, A., LaFranchi, B. W., Guilderson, T. P., Fischer, M. L., and Turnbull, J. C.: Allocation of terrestrial carbon sources using ${ }^{14} \mathrm{CO}_{2}$ : measurement and modeling, Radiocarbon, 55, 1484-1495, 2013.

Levin, I. and Karstens, U. T. E.: Inferring high-resolution fossil fuel $\mathrm{CO}_{2}$ records at continental sites from combined ${ }^{14} \mathrm{CO}_{2}$ and CO observations, Tellus B, 59, 245-250, doi:10.1111/j.16000889.2006.00244.x, 2007.

Levin, I. and Kromer, B.: The tropospheric $\left(\mathrm{CO}_{2}\right)-\mathrm{C}_{14}$ level in midlatitudes of the Northern Hemisphere (1959-2003), Radiocarbon, 46, 1261-1272, 2004.

Levin, I., Kromer, B., Schmidt, M., and Sartorius, H.: A novel approach for independent budgeting of fossil fuel $\mathrm{CO}_{2}$ over Europe by $\left(\mathrm{CO}_{2}\right)-\mathrm{C}_{14}$ observations, Geophys. Res. Lett., 30, 2194, doi:10.1029/2003GL018477, 2003.

Levin, I., Naegler, T., Kromer, B., Diehl, M., Francey, R. J., GomezPelaez, A. J., Steele, L. P., Wagenbach, D., Weller, R., and Worthy, D. E.: Observations and modelling of the global distribution and long-term trend of atmospheric ${ }^{14} \mathrm{CO}_{2}$, Tellus B, 62, 26-46, 2010.

Miller, J. B., Lehman, S. J., Montzka, S. A., Sweeney, C., Miller, B. R., Wolak, C., Dlugokencky, E. J., Southon, J., Turnbull, J. C., and Tans, P. P.: Linking emissions of fossil fuel $\mathrm{CO}_{2}$ and other anthropogenic trace gases using atmospheric ${ }^{14} \mathrm{CO}_{2}$, J. Geophys. Res. Atmos., D08302, doi:10.1029/2011JD017048, 2012.

Miller, S. M., Matross, D. M., Andrews, A. E., Millet, D. B., Longo, M., Gottlieb, E. W., Hirsch, A. I., Gerbig, C., Lin, J. C., Daube, B. C., Hudman, R. C., Dias, P. L. S., Chow, V. Y., and Wofsy, S. C.: Sources of carbon monoxide and formaldehyde in North America determined from high-resolution atmospheric data, Atmos. Chem. Phys., 8, 7673-7696, doi:10.5194/acp-8-7673-2008, 2008.

Montzka, S. A., Myers, R. C., Butler, J. H., Elkins, J. W., and Cummings, S. O.: Global Tropospheric Distribution and Calibration Scale of Hcfc-22, Geophys. Res. Lett., 20, 703-706, 1993.

Muller, S. A., Joos, F., Plattner, G. K., Edwards, N. R., and Stocker, T. F.: Modeled natural and excess radiocarbon: Sensitivities to the gas exchange formulation and ocean transport strength, Global Biogeochem. Cy., 22, GB3011, doi:10.1029/2007GB003065, 2008.

NASA: Chemical Kinetics and Photochemical Data for Use in Atmospheric Studies Evaluation Number 15: http://jpldataeval.jpl. nasa.gov/ (last access: 28 June 2010), 2006.

Nassar, R., Napier-Linton, L., Gurney, K. R., Andres, R. J., Oda, T., Vogel, F. R., and Deng, F.: Improving the temporal and spatial distribution of $\mathrm{CO}_{2}$ emissions from global fossil fuel emission datasets, J. Geophys. Res. Atmos., 118, 917-933, doi:10.1029/2012jd018196, 2013.

National Emissions Inventory: http://www.epa.gov/ttn/chief/ eiinformation.html (last access: 26 January 2011), 2008.

Novelli, P. C., Connors, V. S., Reichle, H. G., Anderson, B. E., Brenninkmeijer, C. A. M., Brunke, E. G., Doddridge, B. G., Kirchhoff, V. W. J. H., Lam, K. S., Masarie, K. A., Matsuo, T., Parrish, D. D., Scheel, H. E., and Steele, L. P.: An internally consistent set of globally distributed atmospheric carbon monoxide mixing ratios developed using results from an intercomparison of measurements, J. Geophys. Res. Atmos., 103, 19285-19293, 1998. 
Parrish, D. D.: Critical evaluation of US on-road vehicle emission inventories, Atmos. Environ., 40, 2288-2300, 2006.

Pétron, G., Frost, G., Hirsch, A. I., Montzka, S. A., Karion, A., Miller, B. R., Trainer, M., Sweeney, C., Andrews, A. E., Miller, L., Kofler, J., Ryerson, T., Patrick, L., Siso, C., Kolodzey, W., Lang, P., Dlugokencky, E., Conway, T., Novelli, P., Masarie, K., Hall, B., Guenther, D., Kitzis, D., Miller, J. B., Neff, W., Wolfe, D., and Tans, P. P.: Hydrocarbon emissions characterization in the Colorado front range - A pilot study, J. Geophys. Res. Atmos., 117, D04304, doi:10.1029/2011JD016360, 2012.

Schuur, E. A. G., Trumbore, S. E., Mack, M. C., and Harden, J. W.: Isotopic composition of carbon dioxide from a boreal forest fire: Inferring carbon loss from measurements and modeling, Global Biogeochem. Cy., 17, 1001, doi:10.1029/2001GB001840, 2003.

Stuiver, M. and Polach, H. A.: Reporting of $\mathrm{C}_{14}$ Data - Discussion, Radiocarbon, 19, 355-363, 1977.

Suess, H. E.: Radiocarbon Concentration in Modern Wood, Science, 122, 415-417, 1955.

Sweeney, C., Gloor, E., Jacobson, A. R., Key, R. M., McKinley, G., Sarmiento, J. L., and Wanninkhof, R.: Constraining global air-sea gas exchange for $\mathrm{CO}_{2}$ with recent bomb (14)C measurements, Global Biogeochem. Cy., 21, GB2015, doi:10.1029/2006GB002784, 2007.

Thompson, M. V. and Randerson, J. T.: Impulse response functions of terrestrial carbon cycle models: method and application, Glob. Change Biol., 5, 371-394, 1999.

Thoning, K. W., Tans, P. P., and Komhyr, W. D.: Atmospheric Carbon-Dioxide at Mauna Loa Observatory .2. Analysis of the NOAA GMCC Data, 1974-1985, J. Geophys. Res. Atmos., 94, 8549-8565, 1989.

Turnbull, J., Rayner, P., Miller, J., Naegler, T., Ciais, P., and Cozic, A.: On the use of (14) $\mathrm{CO}_{2}$ as a tracer for fossil fuel $\mathrm{CO}_{2}$ : Quantifying uncertainties using an atmospheric transport model, J. Geophys. Res. Atmos., 114, D22302, doi:10.1029/2009JD012308, 2009.

Turnbull, J. C., Miller, J. B., Lehman, S. J., Tans, P. P., Sparks, R. J., and Southon, J.: Comparison of $\left(\mathrm{CO}_{2}\right)-\mathrm{C}_{14}, \mathrm{CO}$, and SF6 as tracers for recently added fossil fuel $\mathrm{CO}_{2}$ in the atmosphere and implications for biological $\mathrm{CO}_{2}$ exchange, Geophys. Res. Lett., 33, L01817, doi:10.1029/2005GL024213, 2006.

Turnbull, J. C., Lehman, S. J., Miller, J. B., Sparks, R. J., Southon, J. R., and Tans, P. P.: A new high precision ${ }^{14} \mathrm{CO}_{2}$ time series for North American continental air, J. Geophys. Res. Atmos., 112, D11310, doi:10.1029/2006JD008184, 2007.

Turnbull, J. C., Lehman, S. J., Morgan, S., and Wolak, C.: A New Automated Extraction System for (14)C Measurement for Atmospheric $\mathrm{CO}_{2}$, Radiocarbon, 52, 1261-1269, 2010.
Turnbull, J. C., Karion, A., Fischer, M. L., Faloona, I., Guilderson, T., Lehman, S. J., Miller, B. R., Miller, J. B., Montzka, S., Sherwood, T., Saripalli, S., Sweeney, C., and Tans, P. P.: Assessment of fossil fuel carbon dioxide and other anthropogenic trace gas emissions from airborne measurements over Sacramento, California in spring 2009, Atmos. Chem. Phys., 11, 705-721, doi:10.5194/acp-11-705-2011, 2011.

US Energy Information Administration $\mathrm{CO}_{2}$ Emissions Data: http: //www.eia.gov/environment/data.cfm\#summary (last access: 18 June 2012), 2012.

Van der Laan, S., Karstens, U., Neubert, R. E. M., Van der LaanLuijkx, I. T., and Meijer, H. A. J.: Observation-based estimates of fossil fuel-derived $\mathrm{CO}_{2}$ emissions in the Netherlands using Delta 14C, CO and 222Radon, Tellus B, 62, 389-402, 2010.

Vaughn, B. H., Miller, J. B., Ferretti, D. F., and White, J. C.: Stable isotope measurements of atmospheric $\mathrm{CO}_{2}$ and $\mathrm{CH} 4$, in: Handbook of Stable Isotope Analytical Techniques, edited by: de Groot, P., Elsevier Inc., San Diego, CA, USA, 272-304, 2004.

Vay, S. A., Choi, Y., Vadrevu, K. P., Blake, D. R., Tyler, S. C., Wisthaler, A., Hecobian, A., Kondo, Y., Diskin, G. S., Sachse, G. W., Woo, J. H., Weinheimer, A. J., Burkhart, J. F., Stohl, A., and Wennberg, P. O.: Patterns of $\mathrm{CO}_{2}$ and radiocarbon across high northern latitudes during International Polar Year 2008, J. Geophys. Res. Atmos., 116, D14301, doi:10.1029/2011JD015643, 2011.

Wallace, H. W., Jobson, B. T., Erickson, M. H., McCoskey, J. K., VanReken, T. M., Lamb, B. K., Vaughan, J. K., Hardy, R. J., Cole, J. L., Strachan, S. M., and Zhang, W.: Comparison of wintertime $\mathrm{CO}$ to $\mathrm{NO}_{\mathrm{x}}$ ratios to MOVES and MOBILE6.2 on-road emissions inventories, Atmos. Environ., 63, 289-297, doi:10.1016/j.atmosenv.2012.08.062, 2012.

Warneke, C., McKeen, S. A., de Gouw, J. A., Goldan, P. D., Kuster, W. C., Holloway, J. S., Williams, E. J., Lerner, B. M., Parrish, D. D., Trainer, M., Fehsenfeld, F. C., Kato, S., Atlas, E. L., Baker, A., and Blake, D. R.: Determination of urban volatile organic compound emission ratios and comparison with an emissions database, J. Geophys. Res. Atmos., 112, D10S47, doi:10.1029/2006JD007930, 2007.

Watson, J. G., Chow, J. C., and Fujita, E. M.: Review of volatile organic compound source apportionment by chemical mass balance, Atmos. Environ., 35, 1567-1584, 2001.

Whitby, R. A. and Altwicker, E. R.: Acetylene in Atmosphere - Sources, Representative Ambient Concentrations and Ratios to Other Hydrocarbons, Atmos. Environ., 12, 1289-1296, doi:10.1016/0004-6981(78)90067-7, 1978.

Zondervan, A. and Meijer, H. A. J.: Isotopic characterisation of $\mathrm{CO}_{2}$ sources during regional pollution events using isotopic and radiocarbon analysis, Tellus B, 48, 601-612, 1996. 